\title{
Endoplasmic-Reticulum Calcium Depletion and Disease
}

\author{
Djalila Mekahli*, Geert Bultynck*, Jan B. Parys, Humbert De Smedt, and Ludwig Missiaen
}

Laboratory of Molecular and Cellular Signaling, Department of Molecular Cell Biology,

K.U.Leuven Campus Gasthuisberg O\&N I, Herestraat 49, 3000 Leuven, Belgium

Correspondence: Ludwig.Missiaen@med.kuleuven.be

\begin{abstract}
The endoplasmic reticulum (ER) as an intracellular $\mathrm{Ca}^{2+}$ store not only sets up cytosolic $\mathrm{Ca}^{2+}$ signals, but, among other functions, also assembles and folds newly synthesized proteins. Alterations in ER homeostasis, including severe $\mathrm{Ca}^{2+}$ depletion, are an upstream event in the pathophysiology of many diseases. On the one hand, insufficient release of activator $\mathrm{Ca}^{2+}$ may no longer sustain essential cell functions. On the other hand, loss of luminal $\mathrm{Ca}^{2+}$ causes ER stress and activates an unfolded protein response, which, depending on the duration and severity of the stress, can reestablish normal ER function or lead to cell death. We will review these various diseases by mainly focusing on the mechanisms that cause $\mathrm{ER} \mathrm{Ca}^{2+}$ depletion.
\end{abstract}

Cytosolic $\left[\mathrm{Ca}^{2+}\right]\left(\left[\mathrm{Ca}^{2+}\right]_{\mathrm{cyt}}\right)$ is precisely regulated in time and space because $\mathrm{Ca}^{2+}$ controls essential cell functions like proliferation, differentiation, secretion, contraction, metabolism, trafficking, gene transcription and apoptosis, and in this way controls complex processes like development or learning behavior (Berridge et al. 2000). An abnormal $\left[\mathrm{Ca}^{2+}\right]_{\mathrm{cyt}}$ caused by disturbances of $\mathrm{Ca}^{2+}$ channels, $\mathrm{Ca}^{2+}$ transporters, $\mathrm{Ca}^{2+}$ pumps, and $\mathrm{Ca}^{2+}$-binding proteins can induce multiple pathologies (Missiaen et al. 2000). $\mathrm{Ca}^{2+}$ channelopathies in the nervous system leading to paralysis, ataxia, or migraine can be caused by mutations in subunits of voltage-operated $\mathrm{Ca}^{2+}$ channels in the plasma membrane (Bidaud et al. 2006; Lorenzon and Beam 2008). Other channelopathies like malignant hyperthermia and central core disease in skeletal muscle, and some tachycardias and tachyarrhythmias in the heart are because of mutations in $\mathrm{Ca}^{2+}$-release channels or $\mathrm{Ca}^{2+}$-binding proteins of the sarcoplasmic reticulum (SR) (Durham et al. 2007; Lorenzon and Beam 2008; Blayney and Lai 2009; Gyorke 2009). Deafness and skin diseases can also be because of mutations in $\mathrm{Ca}^{2+}$ pumps (Foggia and Hovnanian 2004; Van Baelen et al. 2004; Brini and Carafoli 2009). $\mathrm{Ca}^{2+}$ dysregulation may also lead to more complex diseases like Alzheimer and other neurodegenerative diseases (Bezprozvanny 2009; Berridge 2010; Supnet and Bezprozvanny 2010).

Disease states associated with a decreased $\left[\mathrm{Ca}^{2+}\right]$ in the lumen of the ER $\left(\left[\mathrm{Ca}^{2+}\right]_{\mathrm{ER}}\right)$ have thus far received less attention. The ER controls the synthesis, modification, folding, and export of proteins. An imbalance between the demand for protein synthesis and the capacity to handle

*Both authors contributed equally to this work.

Editors: Martin D. Bootman, Michael J. Berridge, James W. Putney, and H. Llewelyn Roderick

Additional Perspectives on Calcium Signaling available at www.cshperspectives.org

Copyright (C) 2011 Cold Spring Harbor Laboratory Press; all rights reserved; doi: 10.1101/cshperspect.a004317

Cite this article as Cold Spring Harb Perspect Biol 2011;3:a004317 
D. Mekahli et al.

them leads to the accumulation of misfolded or unfolded proteins, which is referred to as ER stress. An unfolded protein response (UPR) is initiated to reestablish normal ER function (Schroder and Kaufman 2005; Ron and Walter 2007). If the stress is too prolonged or severe to be corrected, the adaptive response triggered by the UPR will not overcome the ER stress and a cell-death program is triggered to eliminate the damaged cell. Many diseases affect the ER environment leading to ER stress, a UPR, and apoptosis (Xu et al. 2005; Lindholm et al. 2006; $\mathrm{Kim}$ et al. 2008). Some of them first deplete $\mathrm{ER} \mathrm{Ca}^{2+}$, with disturbed function of luminal proteins (Michalak et al. 2002). The decreased $\left[\mathrm{Ca}^{2+}\right]_{\mathrm{ER}}$, rather than the increased $\left[\mathrm{Ca}^{2+}\right]_{\mathrm{cyt}}$, then triggers apoptosis (Nakano et al. 2006; Yoshida et al. 2006).

We will review the diseases in which a decreased $\left[\mathrm{Ca}^{2+}\right]_{\mathrm{ER}}$ is an upstream event in the pathophysiology and show that ER stress often plays an essential role. We will first briefly review the mechanisms controlling the $\left[\mathrm{Ca}^{2+}\right]_{\mathrm{ER}}$, then focus on how ER stress leads to apoptosis, and finally review the mechanisms of $\mathrm{ER} \mathrm{Ca}^{2+}$ depletion in the various diseases.

\section{$\mathrm{Ca}^{2+}$ HOMEOSTASIS IN THE ER/SR}

To function as an intracellular $\mathrm{Ca}^{2+}$ store, the ER/SR needs to express at least three different types of proteins (Pozzan et al. 1994): (1) $\mathrm{Ca}^{2+}$ pumps for uphill transport of $\mathrm{Ca}^{2+}$ from the cytosol to the lumen; (2) luminal $\mathrm{Ca}^{2+}$-binding proteins for storing $\mathrm{Ca}^{2+}$; and (3) $\mathrm{Ca}^{2+}$ channels for the controlled release of $\mathrm{Ca}^{2+}$ to the cytosol along its electrochemical gradient. Although the ER is generally assumed to form a continuous compartment, it can be heterogeneous at the level of its $\mathrm{Ca}^{2+}$-handling proteins. A heterogeneous distribution allows on the one hand localized $\mathrm{Ca}^{2+}$ pumping and release, and on the other hand, the setting up of $\mathrm{Ca}^{2+}$ signals without disturbing $\mathrm{Ca}^{2+}$-dependent processes within the ER lumen (Petersen et al. 2001; Berridge 2002; Papp et al. 2003).

$\mathrm{Ca}^{2+}$ pumps of the SERCA type (sarco/ endoplasmic-reticulum $\mathrm{Ca}^{2+}$-ATPase) actively pump $\mathrm{Ca}^{2+}$ into the store (Fig. 1). They are encoded by three different genes, whereby each of them exists as various splice variants. SER$\mathrm{CA} 2 \mathrm{~b}$ has the highest $\mathrm{Ca}^{2+}$ affinity and is the most ubiquitous pump. Other isoforms have a more restricted expression pattern. Thapsigargin is a much-used specific inhibitor of the SERCA pumps. This sesquiterpene lactone irreversibly interacts with their M3-transmembrane helix. Phospholamban is the major endogenous regulator of SERCA pumps (at least for isoforms 1a, 2a, and 2b), but it is only expressed in muscle cells. This small protein decreases their $\mathrm{Ca}^{2+}$ affinity (Brini and Carafoli 2009; Vangheluwe et al. 2009).

$\mathrm{Ca}^{2+}$ in the lumen of the ER/SR is buffered by $\mathrm{Ca}^{2+}$-binding proteins. Calsequestrin is the main $\mathrm{Ca}^{2+}$-binding protein in skeletal and cardiac muscle (Beard et al. 2004). In other tissues $\mathrm{Ca}^{2+}$ binds to calreticulin (Michalak et al. 2002) and other $\mathrm{Ca}^{2+}$-dependent chaperones like calnexin, $78-\mathrm{kDa}$ glucose-regulated protein/ immunoglobulin heavy chain binding protein (GRP78/BiP), GRP94, and various proteindisulfide isomerases (PDI) (Papp et al. 2003). All these proteins combine at least two of the following three properties: $\mathrm{Ca}^{2+}$ binding, regulation of $\mathrm{Ca}^{2+}$ pumps or $\mathrm{Ca}^{2+}$-release channels, and chaperone function (Berridge 2002; Papp et al. 2003), emphasizing the close interrelation between the $\left[\mathrm{Ca}^{2+}\right]_{\mathrm{ER}}$ and ER function.

The main $\mathrm{Ca}^{2+}$-release channels in the ER/ SR belong to either the ryanodine-receptor (RyR) (Zalk et al. 2007) or the inositol 1,4,5-trisphosphate $\left(\mathrm{IP}_{3}\right)$-receptor $\left(\mathrm{IP}_{3} \mathrm{R}\right)$ (Foskett et al. 2007) families. In each family, three genes code for receptor subunits, which assemble to produce very large tetrameric $\mathrm{Ca}^{2+}$-release channels ( 2.2 MDa for the RyRs, $1.2 \mathrm{MDa}$ for the $\left.\mathrm{IP}_{3} \mathrm{Rs}\right)$. Further diversity occurs by alternative splicing and by the formation of both homoand, at least for the $\mathrm{IP}_{3} \mathrm{R}$, heterotetramers. The differences in channel and regulatory properties, and in subcellular localization, allow highly specific $\mathrm{Ca}^{2+}$ signals propagating through the cell. RyRs are predominantly expressed in muscles and neurons although they can also be present at low levels in other cells. Skeletal muscle expresses mainly RyR1, which is activated by direct interaction with L-type voltage-operated 


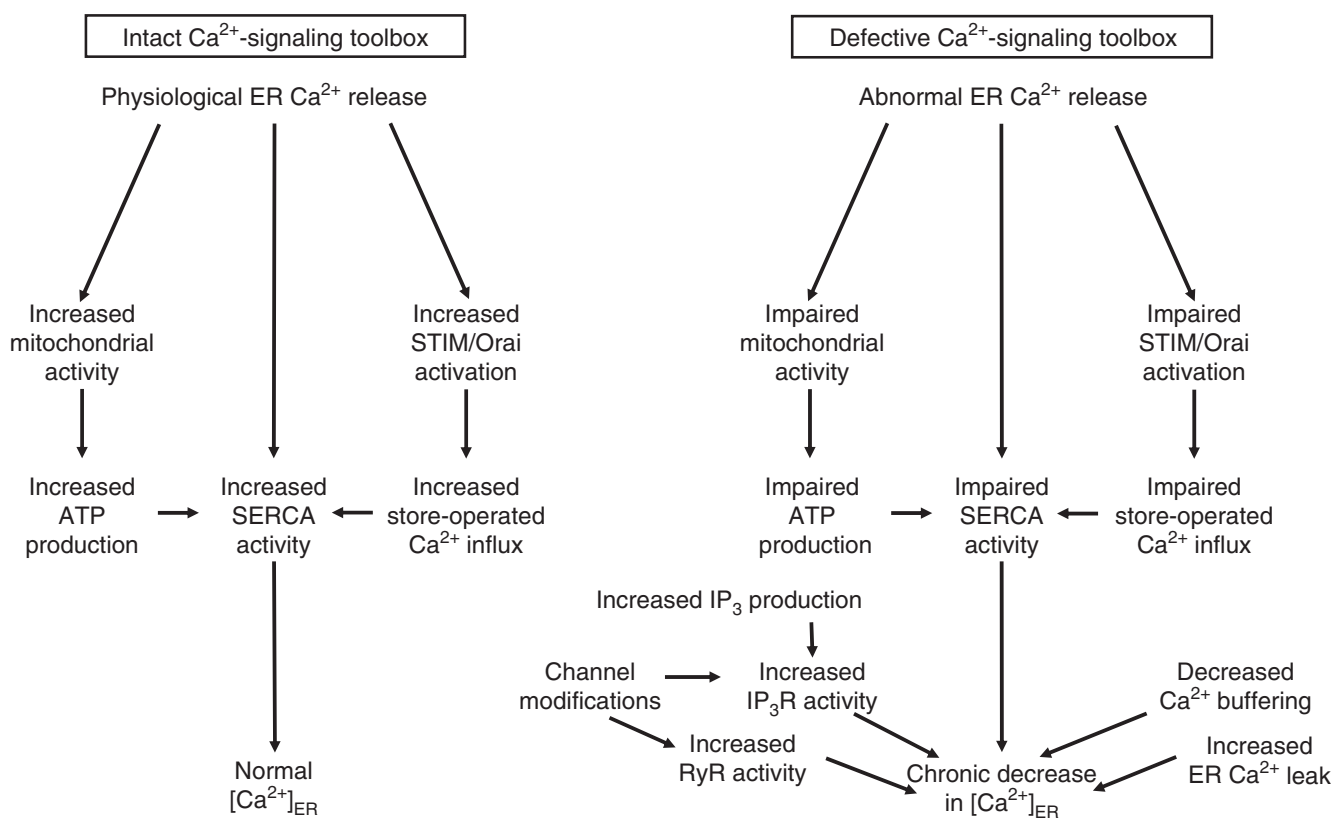

Figure 1. Normal and abnormal $\left[\mathrm{Ca}^{2+}\right]_{\mathrm{ER}}$. A tight coordination between $\mathrm{ER} \mathrm{Ca}^{2+}$-release and -refilling mechanisms enables proper $\mathrm{Ca}^{2+}$ signaling in response to physiological stimuli. Under these conditions, $\mathrm{Ca}^{2+}$ released from the ER stimulates mitochondrial activity and bioenergetics, leading to more ATP production. The initial decline in $\left[\mathrm{Ca}^{2+}\right]_{\mathrm{ER}}$ activates STIM, allowing for store-operated $\mathrm{Ca}^{2+}$ influx. $\mathrm{Ca}^{2+}$ is recycled via the SERCA pumps. Normal $\left[\mathrm{Ca}^{2+}\right]_{\mathrm{ER}}$ is restored and ER-related processes continue. In contrast, in pathological conditions, stress responses will occur and affect the $\mathrm{Ca}^{2+}$-signaling toolbox in various ways. Impaired mitochondrial activity, store-operated $\mathrm{Ca}^{2+}$ influx, or SERCA activity may all cause failure in restoring normal $\left[\mathrm{Ca}^{2+}\right]_{\mathrm{ER}}$ in response to ER $\mathrm{Ca}^{2+}$-signaling processes, and lead to a decreased $\left[\mathrm{Ca}^{2+}\right]_{\mathrm{ER}}$. A chronic decrease in $\left[\mathrm{Ca}^{2+}\right]_{\mathrm{ER}}$ may also be because of an imbalance between the $\mathrm{Ca}^{2+}$-on and -off mechanisms as a result of increased $\mathrm{IP}_{3} \mathrm{R}$ or RyR activity, decreased $\mathrm{Ca}^{2+}$ buffering, or increased $\mathrm{ER} \mathrm{Ca}^{2+}$ leak.

$\mathrm{Ca}^{2+}$ channels, whereas the RyR2 in cardiac tissue and the RyR3 are activated by $\mathrm{Ca}^{2+}$ itself (Endo 2009). $\mathrm{IP}_{3}$ Rs on the other hand are expressed in all cell types. They generally become active when $\mathrm{IP}_{3}$ is produced on cell stimulation by extracellular agonists. $\mathrm{IP}_{3}$ binding at the amino terminus of the receptor induces channel opening at its carboxyl terminus (Bosanac et al. 2004). The further regulation of channel opening by cytosolic factors including $\mathrm{Ca}^{2+}$, by regulatory proteins, and by phosphorylation/ dephosphorylation, as well as their subcellular localization allow them to set up highly specific spatio-temporal $\mathrm{Ca}^{2+}$ signals (Vermassen et al. 2004; Foskett et al. 2007; Mikoshiba 2007; Vanderheyden et al. 2009).

In normal conditions, several mechanisms are operative to prevent $\mathrm{ER} \mathrm{Ca}^{2+}$ depletion or overload, e.g., both $\mathrm{Ca}^{2+}$ channels and $\mathrm{Ca}^{2+}$ pumps are sensitive to luminal $\left[\mathrm{Ca}^{2+}\right]$. The $\mathrm{IP}_{3} \mathrm{R}$ becomes more sensitive to $\mathrm{IP}_{3}$ when the $\left[\mathrm{Ca}^{2+}\right]_{\mathrm{ER}}$ increases (Irvine 1990; Missiaen et al. 1992) and also the RyR is stimulated by luminal $\mathrm{Ca}^{2+}$ (Nelson and Nelson 1990; Gyorke and Terentyev 2008). SERCA-mediated $\mathrm{Ca}^{2+}$ uptake into the ER is sensitive to $\left[\mathrm{Ca}^{2+}\right]_{\mathrm{ER}}$ (Takenaka et al. 1982). The release of $\mathrm{Ca}^{2+}$ from the ER during the generation of cytosolic $\mathrm{Ca}^{2+}$ signals should not decrease the $\left[\mathrm{Ca}^{2+}\right]_{\mathrm{ER}}$ to a level at which ER function and $\mathrm{Ca}^{2+}$ signaling become compromised (Sammels et al. 2010). A mechanism has evolved that couples $\mathrm{ER} \mathrm{Ca}^{2+}$ depletion to an increase of $\mathrm{Ca}^{2+}$ entry into the cell. This phenomenon is known as "capacitative" (Putney 1986) or "store-operated" $\mathrm{Ca}^{2+}$ entry. STIM1 and STIM2 are ubiquitously expressed 
D. Mekahli et al.

single-pass transmembrane ER and, to some extent, plasma-membrane proteins with a luminal $\mathrm{Ca}^{2+}$ sensor (Stathopulos et al. 2008). Depending on the extent of ER depletion, either STIM1 or STIM2 oligomerize and interact with Orail proteins (Brandman et al. 2007). These tetrameric $\mathrm{Ca}^{2+}$ channels in the plasma membrane are then responsible for an increased $\mathrm{Ca}^{2+}$ entry (Cahalan 2009; Deng et al. 2009; Schindl et al. 2009).

\section{ER STRESS AND APOPTOSIS}

The ER not only fulfills a crucial role in $\mathrm{Ca}^{2+}$ signaling, but also provides a quality-control system for the proper folding of proteins and for sensing stress (Fig. 2). A plethora of ERresident chaperones including calreticulin, calnexin, PDI, and GRP78/BiP bind unfolded or misfolded proteins via inappropriately exposed hydrophobic or hypo-glycosylated residues (Austin 2009). Calreticulin and calnexin bind to polypeptide chains entering the ER lumen through glycosylated residues, whereas PDI mediates the correct formation of disulfide bonds. GRP78/BiP undergoes cycles of binding and release of unfolded proteins until they are properly folded and hydrophobic residues are inaccessible. ER-resident chaperones like calreticulin, GRP78/BiP, and GRP94 need a high $\left[\mathrm{Ca}^{2+}\right]_{\mathrm{ER}}$ for their activity (Ma and Hendershot 2004) with $\mathrm{Ca}^{2+}$ binding to paired anionic amino acids (Lucero and Kaminer 1999). Moreover, several of the ER chaperones also act as $\mathrm{Ca}^{2+}$ buffers (Lievremont et al. 1997; Papp et al. 2003). Determination of the $\mathrm{Ca}^{2+}$ affinities suggests up to millimolar levels in the ER (Sambrook 1990), and depletion of ER $\mathrm{Ca}^{2+}$ by treating cells with a $\mathrm{Ca}^{2+}$ ionophore or thapsigargin can lead to inappropriate secretion, aggregation, and degradation of unassembled proteins (Gaut and Hendershot 1993).

The $\left[\mathrm{Ca}^{2+}\right]_{\mathrm{ER}}$ must be maintained in an environment of continuous intracellular $\mathrm{Ca}^{2+}$ signaling. Failure of this homeostatic mechanism, for example, by inhibition of SERCA with thapsigargin, triggers a UPR to either reestablish normal ER function or to eliminate the cell $(\mathrm{Xu}$ et al. 2005). The adaptive mechanisms initiated by the UPR involve reduced translation of misfolded proteins, enhanced translation of ER chaperones to increase the folding capacity of the ER, and degradation of misfolded proteins through ER-assisted degradation (ERAD) (Schroder and Kaufman 2005; Malhotra and Kaufman 2007). Global mRNA translation is inhibited for a few hours to reduce the influx of new proteins into the ER, whereas alarm signals involving the activation of mitogenactivated protein kinases (MAPK) are induced (Kim et al. 2008). The UPR involves three signaling pathways: PERK (PKR-like ER kinase), Ire1 (inositol-requiring enzyme 1), and ATF6 (activating transcription factor 6).

The recognition of misfolded proteins by the Ser/Thr kinase PERK leads to phosphorylation and inactivation of the eukaryotic initiation factor $2 \alpha(\mathrm{eIF} 2 \alpha)$. This shuts off mRNA translation, thereby preventing the accumulation of newly synthesized proteins in the ER (Harding et al. 1999), activates the transcription factor ATF4, which increases the level of chaperones such as GRP78/BiP and GRP94, and helps to restore the cellular redox homeostasis (Harding et al. 2000, 2003).

Ire1 has endoribonuclease and Ser/Thrkinase activity. Its endoribonuclease activity degrades many mRNAs to reduce the protein load on the ER (Hollien and Weissman 2006). Ire1 removes an intron from the mRNA of X-box-binding protein 1 (XBP1), leading to the expression of XBP1. This transcription factor is involved in the expression of several UPR and ERAD genes (Rao and Bredesen 2004). The kinase activity of Ire 1 is involved in apoptotic signaling via ASK1 (apoptosis signal-regulating kinase 1) and JNK (c-Jun N-terminal kinase). JNK activates the proapoptotic $\mathrm{BH} 3$-only protein Bim (Lei and Davis 2003; Putcha et al. 2003), and inactivates the antiapoptotic Bcl-2 protein (Yamamoto et al. 1999). Ire1 also recruits caspase 12 (Yoneda et al. 2001), which may play a role in ER stress-induced apoptosis (Szegezdi et al. 2003). However, caspase 12 is not present in humans, and although caspase 4 , its close paralogue, may perform such function, it remains uncertain whether caspase 4 is vital for ER stress-induced apoptosis (Egger et al. 2003). 

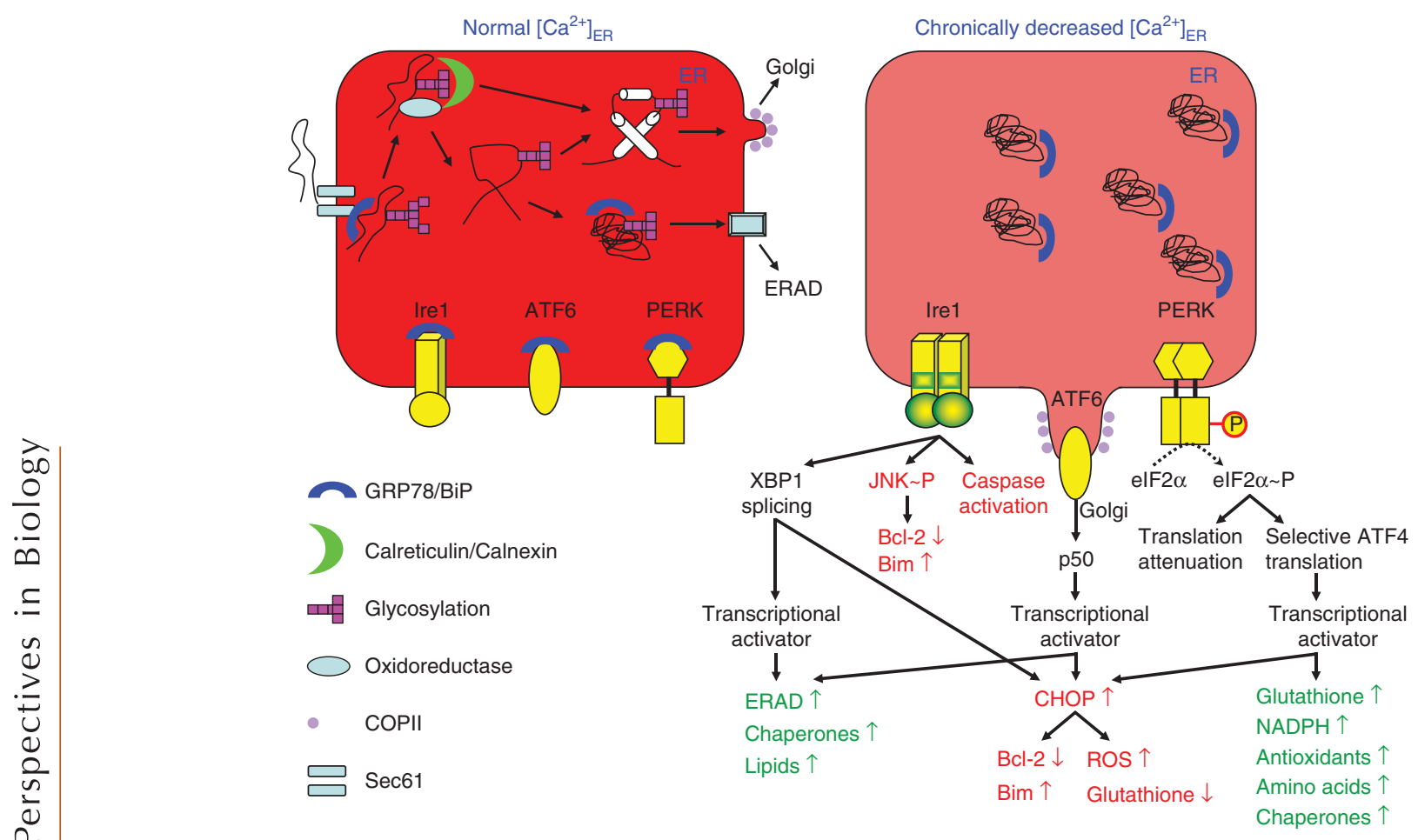

Figure 2. The UPR. At a normal $\left[\mathrm{Ca}^{2+}\right]_{\mathrm{ER}}$ the ER-stress sensors are scaffolded and inactivated by GRP78/BiP. Protein trafficking and quality-control mechanisms work normally. Polypeptides are translocated through Sec61 and glycosylated. This transport is facilitated by the molecular chaperone GRP78/BiP. Glucosidases then prepare the glycoprotein for binding to the ER lectins, calreticulin, and calnexin, whereas oxidoreductases catalyze disulfide-bond formation. ER-resident chaperones facilitate the proper folding of the nascent protein and prevent its aggregation. Further deglucosidation releases the ER lectins and once the protein is correctly folded and processed, the protein leaves the ER via the coat protein (COPII)-coated vesicles to the secretory pathway. Misfolded proteins, in contrast, associate with various chaperones, including GRP78/BiP, and are removed from the ER through ERAD.

In contrast, when the $\left[\mathrm{Ca}^{2+}\right]_{\mathrm{ER}}$ is chronically decreased, the function of chaperones becomes disturbed and unfolded proteins accumulate and act as a sponge for luminal GRP78/BiP. As a consequence, ER-stress sensors are devoid of GRP78/BiP and become activated, yielding early adaptive responses promoting survival (indicated in green) or late responses promoting apoptosis under conditions of severe or on-going ER stress (indicated in red). Ire1 undergoes dimerization and activation of its kinase and endoribonuclease activity, thereby splicing XBP1 mRNA and yielding a potent transcriptional activator that induces the expression of genes involved in ERAD, protein folding (like GRP78/BiP), and lipid synthesis. ATF6 goes to the Golgi compartment, where it is proteolytically cleaved to yield a cytosolic fragment (p50) that migrates to the nucleus and activates the transcription of UPR genes, like GRP78/BiP and CHOP. PERK dimerizes, autophosphorylates, and phosphorylates eIF $2 \alpha$, thereby suppressing its activity and reducing the rate of translation initiation, while increasing the rate of translation of ATF4, a potent transcription factor that augments the expression of genes involved in antioxidative stress, amino acid metabolism, and protein chaperoning. During on-going ER stress or irreparable ER damage, apoptotic pathways are activated. Ire1 phosphorylates JNK, leading to inhibition of Bcl-2 activity and activation of Bim, and recruits, releases, and activates procaspases in the cytosol. Induction of CHOP via XBP1, ATF6 or ATF4, down-regulates prosurvival Bcl-2-family members, increases prodeath proteins (like Bim) and ROS, and decreases the levels of glutathione, a ROS scavenger. In the presence of ROS, $\mathrm{Ca}^{2+}$ transfer to the mitochondria leads to the release of cytochrome $c$. The balance between proapoptotic and antiapoptotic Bcl-2-family members is disturbed, with activation of the intrinsic apoptotic pathway. 
D. Mekahli et al.

The transcription factor ATF6 is translocated to the Golgi during ER stress and is proteolytically activated. ATF6 stimulates ER-stress genes as a homodimer or as a heterodimer with other transcription factors like XBP1, whose transcription is also induced by ATF6 (Yoshida et al. 2001; Malhotra and Kaufman 2007). ATF6 is cytoprotective, possibly mediated by RCAN1 (regulator of calcineurin-1), an endogenous inhibitor of calcineurin (Belmont et al. 2008). This enzyme dephosphorylates the proapoptotic Bad ( $\mathrm{Bcl}-2$ antagonist of cell death), which then dimerizes and inhibits antiapoptotic family members such as Bcl-2 and Bcl-Xl (Wang et al. 1999).

ATF4, ATF6, and XBP1 all induce the transcription of the gene encoding $\mathrm{CHOP}(\mathrm{C} /$ EBP homologous protein) (Kim et al. 2008). The Ire1-ASK1-p38-MAPK pathway enhances CHOP activity at a posttranscriptional level (Wang and Ron 1996). CHOP is involved in ER stress-induced apoptosis by down-regulating the antiapoptotic Bcl-2 (McCullough et al. 2001), and by inducing expression of the proapoptotic Bim (Puthalakath et al. 2007) and of ER oxidase $1 \alpha$, thereby rendering the ER more oxidative and exacerbating ER stress (Marciniak et al. 2004). Misfolded proteins are eventually eliminated via proteins involved in the ERAD pathway, which are induced and controlled by both Ire1-XBP1 and ATF6 pathways (Yoshida et al. 2003).

No trigger for ER stress selectively elicits either adaptive responses or apoptosis. The switch between life and death is regulated by the complex interdependent UPR-signaling pathways that each may result in prosurvival or prodeath responses. The different time courses of the three main UPR branches may influence the cell fate (Lin et al. 2007a). The early termination of Ire $1 \alpha$ activity is needed for cell death. Differential activation of PERK and Ire $1 \alpha$ may lead to life or death (Lin et al. 2009). Cell death is induced by apoptosis and by caspase-independent necrosis. ER stress also induces autophagy (Ogata et al. 2006; Bernales et al. 2006; Hoyer-Hansen and Jaattela 2007). The PERKATF4 branch stimulates the expression of ATG12, an autophagy gene (Kouroku et al. 2007). This catabolic process removes unfolded proteins and their aggregates independently of the ubiquitin/ proteasome system, thereby promoting cell survival. Ultimately, however, enhanced autophagic vacuolization may lead to non-apoptotic cell death (Levine and Kroemer 2008).

ER stress and cell death involve many $\mathrm{Ca}^{2+}$ dependent processes (Kim et al. 2008) including phospholipases, scramblases, nitric-oxide (NO) synthases, calpains, calcineurin, FKBP38, fortilin, a putative modulator of Mcl-1 (myeloid cell leukemia sequence 1), death-associated protein kinase 1 , mitochondrial fission, and $\mathrm{Ca}^{2+}$ dependent pathways triggering autophagy. Some pathways require interplay between mitochondria and the ER in zones of close contact (Giorgi et al. 2008, 2009). These microdomains involve the close proximity of $\mathrm{ER} \mathrm{Ca}^{2+}$-release channels like the $\mathrm{IP}_{3} \mathrm{R}$ and mitochondrial $\mathrm{Ca}^{2+}$ transport mechanisms, like the voltage-dependent anion channel (VDAC) and the $\mathrm{Ca}^{2+}$ uniporter (Giorgi et al. 2009). Changes in $\mathrm{ER} \mathrm{Ca}^{2+}$ homeostasis in this way affect mitochondrial $\mathrm{Ca}^{2+}$ signaling. Lowering of the $\left[\mathrm{Ca}^{2+}\right]_{\mathrm{ER}}$ by antiapoptotic proteins such as $\mathrm{Bcl}-2$ has been described (Scorrano et al. 2003) and is expected to lower the sensitivity to apoptotic $\mathrm{Ca}^{2+}$ transfer from the ER to the mitochondria (Rizzuto et al. 2009). Bcl-Xl, a related antiapoptotic protein was found to induce prosurvival ER-tomitochondria $\mathrm{Ca}^{2+}$ signaling by sensitizing the $\mathrm{IP}_{3} \mathrm{R}$ to basal levels of $\mathrm{IP}_{3}$ (White et al. 2005). ER-to-mitochondria $\mathrm{Ca}^{2+}$ signals can regulate cell survival by enhancing mitochondrial bioenergetics. Mitochondrial $\mathrm{Ca}^{2+}$ overload, on the other hand, by a larger or more persistent $\left[\mathrm{Ca}^{2+}\right]$ rise was found to induce cell death (Rong and Distelhorst 2008). Cell death is characterized by mitochondrial outer membrane permeabilization (MOMP) and the loss of the mitochondrial transmembrane potential $\Delta \Psi_{\mathrm{m}}$ (Kroemer et al. 2007). Mitochondrial $\mathrm{Ca}^{2+}$ overload can cause breakdown of $\Delta \Psi_{\mathrm{m}}$ by activating the permeability transition pore (PTP). Loss of $\Delta \Psi_{\mathrm{m}}$, however, seems to be a secondary event and not required for MOMP and the release of cytochrome $c$ (Chipuk and Green 2008). Accordingly, PTP opening probably plays a role in necrosis but not apoptosis. 
Deficiency of Bax and Bak confers resistance to apoptotic cell death induced by conventional anticancer therapies. SERCA inhibitors like thapsigargin, however, can efficiently kill Bax/ $\mathrm{Bak}^{-/-}$MEFs by inducing mitochondrial $\mathrm{Ca}^{2+}$ overload, PTP opening and necrotic cell death (Janssen et al. 2009). In addition to PTP opening, the activation and oligomerization of the executioner proapoptotic Bcl-2-family members Bax and Bak induce MOMP in response to a variety of apoptotic triggers (Chipuk and Green 2008; Brunelle and Letai 2009). The activity of Bax/Bak is tightly controlled by proteins of the Bcl-2 family. The antiapoptotic Bcl-2-family members, including Bcl-2, Bcl-Xl and Mcl-1, neutralize and prevent oligomerization of $\mathrm{Bax} / \mathrm{Bak}$, whereas activator proapoptotic $\mathrm{BH} 3$-only proteins, including Bim, cleaved Bid and cytosolic p53, directly bind to Bax/Bak, causing a conformational change, membrane insertion, and oligomerization. In addition, sensitizer $\mathrm{BH} 3$-only proteins, including Bad, Noxa, and Puma, bind to the antiapoptotic Bcl-2-family members, neutralizing their antiapoptotic activity. Many of these proteins affect ER $\mathrm{Ca}^{2+}$ homeostasis by binding to the $\mathrm{IP}_{3} \mathrm{R}$ and/or changing its phosphorylation, resulting in altered $\mathrm{Ca}^{2+}$-flux properties of the channel (Oakes et al. 2005; White et al. 2005; Rong and Distelhorst 2008).

\section{DIABETES MELLITUS}

Intracellular $\mathrm{Ca}^{2+}$ signaling is perturbed in this chronic metabolic disease with hyperglycemia. Resting $\left[\mathrm{Ca}^{2+}\right]_{\mathrm{cyt}}$ increases, and stimulusinduced $\left[\mathrm{Ca}^{2+}\right]_{\text {cyt }}$ increases in many tissues decrease (Levy 1999; Verkhratsky and Fernyhough 2008). The $\left[\mathrm{Ca}^{2+}\right]_{\mathrm{ER}}$ and SR $\left[\mathrm{Ca}^{2+}\right]\left(\left[\mathrm{Ca}^{2+}\right]_{\mathrm{SR}}\right)$ decrease in the pancreatic $B$-cell and in tissues affected by diabetic complications.

\section{Pancreatic $\beta$-Cell}

The progressive reduction in cell mass and eventually failure of the $ß$-cell is because of apoptotic cell death. ER stress is an important mechanism of apoptosis (Eizirik et al. 2008), at least in some types of diabetes (Akerfeldt et al. 2008). The $\left[\mathrm{Ca}^{2+}\right]_{\mathrm{ER}}$ in the $B$-cell is decreased, but the mechanism involved depends on the type of diabetes. The low $\left[\mathrm{Ca}^{2+}\right]_{\mathrm{ER}}$ impairs proinsulin processing and transport (Guest et al. 1997). The subsequently activated UPR can lead to apoptosis resulting in insufficient insulin secretion (Oyadomari and Mori 2004; Eizirik et al. 2008). The very high secretion rate of $B$-cells makes them very sensitive to apoptosis induced by $\mathrm{ER} \mathrm{Ca}^{2+}$ depletion (Araki et al. 2003; Cardozo et al. 2005; Tonnesen et al. 2009).

Type- 1 diabetes is characterized by an autoimmune $ß$-cell destruction caused by overproduction of NO (Gotoh and Mori 2006). Cytokines released from infiltrating $\mathrm{T}$-cells and macrophages up-regulate inducible $\mathrm{NO}$ synthase in an NF-kB- and STAT-1-dependent manner (Eizirik et al. 2008). NO depletes ER $\mathrm{Ca}^{2+}$ in $\beta$-cells by acting on SERCA and on the $\mathrm{Ca}^{2+}$-release channels (Oyadomari et al. 2001). NO down-regulates SERCA2b expression (Cardozo et al. 2005), perhaps through inhibition of the Sp1 transcription factor (Pirot et al. 2008). NO also reacts with superoxide anion to form peroxynitrite, which inhibits SERCA by reacting with two tyrosine residues in the channel-like domain (Viner et al. 1999; Grover et al. 2003). Peroxynitrite also activates RyR2 by poly-S-nitrosylation of the channel (Xu et al. 1998). The cytokines also up-regulate death protein 5, a $\mathrm{BH} 3$-only protein that contributes to $\mathrm{Ca}^{2+}$ depletion and ER stress (Gurzov et al. 2009). This depletion mainly occurs when $\mathrm{IP}_{3} \mathrm{Rs}$ and RyRs are stimulated (Luciani et al. 2009). Type-1 diabetes was furthermore associated with the single-nucleotide polymorphism $r s 2296336$ in the gene encoding $\mathrm{IP}_{3} \mathrm{R} 3$ (Roach et al. 2006). Increased cholinergic tone with more acetylcholine-induced $\mathrm{IP}_{3}$ production, and up-regulation of the $\mathrm{IP}_{3} \mathrm{R}$ during hyperglycemia (Lee et al. 1999) therefore promote $\mathrm{ER} \mathrm{Ca}^{2+}$ depletion. NO-induced ER stress in B-cells does not activate the ATF6 branch of the UPR (Cardozo et al. 2005; Tonnesen et al. 2009). It is still debated whether cytokine-induced ER stress is a direct cause of B-cell apoptosis or a parallel and/or downstream event (Akerfeldt et al. 2008). 
D. Mekahli et al.

Nonautoimmune type-1 diabetes in Wolfram syndrome is caused by mutations in the gene encoding the ER glycoprotein wolframin (Inoue et al. 1998; Strom et al. 1998). This genetic defect lowers $\left[\mathrm{Ca}^{2+}\right]_{\mathrm{ER}}$ in $B$-cells (Takei et al. 2006) and activates the UPR and triggers the apoptotic pathway (Yamada et al. 2006). Reconstitution of this ER-resident transmembrane protein into planar lipid bilayers induces a cation-selective ion channel (Osman et al. 2003). Wolframin also prevents ER stress via other mechanisms, e.g., by negatively regulating ATF6 $\alpha$ through the ubiquitin-proteasome pathway (Fonseca et al. 2010).

Type-2 diabetes is characterized by insulin resistance in liver, skeletal muscle and adipose tissue, and a failure of the $B$-cell to compensate for the increasing demand. Insulin resistance in liver and adipose tissue may be because of ER stress (van der Kallen et al. 2009). ER Ca ${ }^{2+}$ depletion with thapsigargin leads to insulin resistance (Ozcan et al. 2004), but so far there are no studies linking peripheral insulin resistance to a decreased $\left[\mathrm{Ca}^{2+}\right]_{\mathrm{ER}}$. A high-fat diet or obesity often leads to the development of type-2 diabetes (Eizirik et al. 2008). Free fatty acids trigger $B$-cell loss (Leonardi et al. 2003). One model of lipotoxicity proposes that palmitate activates the UPR in B-cells (Eizirik et al. 2008). The mechanism may again involve ER $\mathrm{Ca}^{2+}$ depletion (Cunha et al. 2008; Gwiazda et al. 2009) by decreased expression (Roe et al. 1994; Evans-Molina et al. 2009) or activity of SERCA (Cunha et al. 2008). Peroxisome proliferator-activated receptor- $\gamma$ (PPAR- $\gamma$ ) agonists, which improve sensitivity to insulin, also restore SERCA expression and attenuate ER stress in the ß-cell (Evans-Molina et al. 2009). Despite variation in the gene encoding SERCA3 in type-2 diabetic patients (Varadi et al. 1999), insulin secretion and blood glucose levels were normal in SERCA3 ${ }^{-/}$mice (Arredouani et al. 2002), probably because of compensatory mechanisms.

Polymorphisms in the gene for insulin receptor substrate 1 (IRS-1) have been linked to type-2 diabetes (Almind et al. 1993). IRS-1 directly interacts with SERCA3 (Borge and Wolf 2003). Mice with deleted IRS-1 have reduced SERCA2b and 3 levels, more transient increases in $\left[\mathrm{Ca}^{2+}\right]_{\text {cyt }}$ and less insulin secretion (Kulkarni et al. 2004).

\section{Diabetic Cardiomyopathy}

The remodeling of the SR resulting in a slower $\mathrm{Ca}^{2+}$ uptake, a lower $\left[\mathrm{Ca}^{2+}\right]_{\mathrm{SR}}$, and release of less activator $\mathrm{Ca}^{2+}$, slows relaxation kinetics of the ventricle and eventually leads to systolic dysfunction, independently of vascular or valve disease (Rubler et al. 1972). Hyperglycemia causes these effects (Ren et al. 1997). The changes in $\mathrm{SR} \mathrm{Ca}^{2+}$ handling depend on the type of diabetes, the experimental model, the degree of hyperglycemia, and the extent of disease progression. SR function is already abnormal at an insulin-resistant stage before the manifestation of overt type-2 diabetes (Dutta et al. 2002; Wold et al. 2005; Vasanji et al. 2006; Reuter et al. 2008).

Phospholamban, which inhibits SERCA2a, becomes up-regulated (Kim et al. 2001; Choi et al. 2002; Belke et al. 2004; Zhou et al. 2006) at an early stage of the disease (Zhong et al. 2001). Its phosphorylation by protein kinase A and $\mathrm{Ca}^{2+} /$ calmodulin-dependent protein kinase, which regulates the interaction with SERCA2a, and therefore stimulates $\mathrm{Ca}^{2+}$ uptake, decreases (Choi et al. 2002; Belke et al. 2004; Vasanji et al. 2004, 2006).

The activity and expression of SERCA2a decrease in the diabetic heart (Teshima et al. 2000; Kim et al. 2001; Trost et al. 2002; Choi et al. 2002; Belke et al. 2004; Vasanji et al. 2004; Wold et al. 2005; Zhang et al. 2008; Stolen et al. 2009; Wang et al. 2010). Reduced activity of SERCA2a is not only because of the effect on phospholamban, but also to increased formation of advanced glycation end products of SERCA2a (Bidasee et al. 2004), depressed activity of protein kinase A (Dutta et al. 2002), and sensory denervation leading to diminished production of $\mathrm{NO}$ and peroxynitrite, which at basal concentrations activate SERCA2a through S-nitrosylation of Cys-349 (Bencsik et al. 2008). The fact that peroxynitrite both stimulates (Adachi et al. 2004) and inhibits SERCA (Viner et al. 1999; Schmidt et al. 2003b) seems to 
indicate that the effect is very much dependent on the experimental conditions or perhaps on the isoform studied. SERCA2a expression decreases in a later stage of the disease (Zhong et al. 2001), perhaps by increased O-glycosylation of the transcription factor Sp1 with $\beta-N$ acetylglucosamine because of the hyperglycemia (Clark et al. 2003), or by reduced expression and activity of SIRT1, a histone deacetylase (Sulaiman et al. 2010). RyR2 function changes by formation of disulfide bonds between adjacent sulfhydryl groups (Bidasee et al. 2003a), by increased glycation (Bidasee et al. 2003b), by decreased FKBP12.6 expression and binding (Belke et al. 2004; Shao et al. 2007), by hyperphosphorylation (Shao et al. 2007; Stolen et al. 2009), and by a reduced density of T-tubules (Stolen et al. 2009). Two RyR populations appear: one with enhanced responsiveness to $\mathrm{Ca}^{2+}$ and another being unresponsive (Shao et al. 2007). Dysfunctional RyR2 can cause dyssynchronous and diastolic $\mathrm{Ca}^{2+}$ releases, sometimes with ventricular arrhythmia (Shao et al. 2007). Spontaneous $\mathrm{Ca}^{2+}$ sparks representing aberrant RyR2 activation increase in frequency (Yaras et al. 2005; Shao et al. 2007). SR Ca ${ }^{2+}$ leak increases (Belke et al. 2004; Stolen et al. 2009). Expression of RyR2 decreases (Teshima et al. 2000; Choi et al. 2002; Guner et al. 2004; Pereira et al. 2006; Zhou et al. 2006; Reuter et al. 2008; Wang et al. 2010) at later stages of the disease (Zhong et al. 2001). $\mathrm{IP}_{3} \mathrm{R} 1,2$, and 3 become down-regulated, but these effects may be species related (Guner et al. 2004; Zhou et al. 2006). The roles of $\mathrm{IP}_{3} \mathrm{Rs}$ in the heart are furthermore not entirely clear.

Some treatments directly affect the $\mathrm{Ca}^{2+}$ signal. Overexpression of SERCA2a protects the heart from contractile dysfunction (Trost et al. 2002; Vetter et al. 2002; Sakata et al. 2007) and reverses established cardiomyopathy (Suarez et al. 2008) and the transcriptional profile induced by diabetes (Karakikes et al. 2009). SERCA2a expression and cardiac function can be normalized by PPAR- $\gamma$ agonists (Shah et al. 2005), total triterpene acids from Cornus officinalis Sieb. (Qi et al. 2008), and the SIRT1 activator resveratrol (Sulaiman et al. 2010). Breviscapine in Chinese medicine decreases phospholamban expression and increases that of SERCA2a and RyR2 (Wang et al. 2010). Exercise training also normalizes abnormal $\mathrm{Ca}^{2+}$ signaling (Shao et al. 2009; Stolen et al. 2009).

\section{Vascular Disease}

Diabetes lowers $\left[\mathrm{Ca}^{2+}\right]_{\mathrm{ER}}$ in the smooth-muscle cells, macrophages and platelets. These changes contribute to the vascular complications including atherosclerosis (Cooper et al. 2001).

In healthy smooth-muscle cells, basal levels of $\mathrm{NO}$ react with superoxide anion to form peroxynitrite, which together with glutathione reacts with Cys-674 of SERCA and increases its activity (Adachi et al. 2004). The hyperglycemia of diabetes induces high levels of oxidants that irreversibly oxidize Cys-674 leading to less $S$-glutathionylation-induced stimulation of SERCA2 (Adachi et al. 2004) and faster degradation (Ying et al. 2008). Insulin also inhibits SERCA via enhanced nitrotyrosine formation (Kobayashi et al. 2007). SERCA2 is also redistributed to a peri-nuclear pattern (Searls et al. 2010). The subsequently decreased $\left[\mathrm{Ca}^{2+}\right]_{\mathrm{ER}}$ stimulates plasma-membrane $\mathrm{Ca}^{2+}$ influx and induces migration of the smooth-muscle cell, which contributes to neointimal hyperplasia and atherosclerosis (Tong et al. 2008). Dedifferentiation of smooth-muscle cells precedes their migration from the media to the intima. The up-regulation of the secretory-pathway $\mathrm{Ca}^{2+}$ ATPase 1 (SPCA1) in diabetes (Lai and Michelangeli 2009) probably reflects the change from a contractile to a secretory cell. Sp1 and YY1, transcription factors controlling SPCA1 transcription (Kawada et al. 2005), become more active in high glucose (Han and Kudlow 1997). The expression of $\mathrm{IP}_{3} \mathrm{R}$ and RyR decreases (Ma et al. 2008; Searls et al. 2010).

Macrophages in type-2 diabetes express more CHOP and are therefore more susceptible to ER stress-induced apoptosis. CHOP induces ER oxidase $1 \alpha$, with hyperoxidation of the ER lumen and disulfide-bond formation between two cysteines in $\mathrm{IP}_{3} \mathrm{R} 1$. This causes dissociation of the disulfide isomerase-like protein ERp44 (Kang et al. 2008) and more $\mathrm{IP}_{3}$-induced $\mathrm{Ca}^{2+}$ 
D. Mekahli et al.

release ( $\mathrm{Li}$ et al. 2009). These changes favor plaque necrosis.

Altered $\mathrm{Ca}^{2+}$ signaling in platelets makes them hyperreactive. Their increased adhesiveness and aggregability contribute to the development of the angiopathy (Knobler et al. 1998). The hyperglycemia causes oxidant stress in platelets (Vericel et al. 2004), which enhances tyrosine nitration of SERCA2 and in this way decreases SERCA2 function and, at least at high $\mathrm{HbA}_{1 \mathrm{C}}$ levels, expression in type2 diabetic patients (Randriamboavonjy et al. 2008). PPAR- $\gamma$ agonists decrease tyrosine nitration of SERCA and increase its expression. Increased levels of homocysteine in type- 2 diabetic patients also release $\mathrm{Ca}^{2+}$ from agonistsensitive $\mathrm{Ca}^{2+}$ stores (Zbidi et al. 2010). The direct stimulatory interaction of STIM1 with SERCA3 is impaired in type-2 diabetes (Lopez et al. 2008), which can explain the increased plasma-membrane $\mathrm{Ca}^{2+}$ entry, and the higher $\left[\mathrm{Ca}^{2+}\right]_{\text {cyt }}$ at rest and during thrombin stimulation (Saavedra et al. 2004). SERCA3b was upregulated in type-1 diabetes (Chaabane et al. 2007). This isoform is involved in cell adhesion (Chaabane et al. 2006) and its up-regulation can thus explain the increased adhesiveness in diabetic patients.

\section{Diabetic Nephropathy}

This complication is an important cause of endstage renal disease. Apoptosis induced by ER stress also occurs in the diabetic kidney (Liu et al. 2008). In podocytes, advanced glycation end products release $\mathrm{ER} \mathrm{Ca}^{2+}$ and trigger a UPR leading to apoptosis during the early stage of the nephropathy (Chen et al. 2008). The loss of podocytes is an important determinant in the progression of the disease. Tubulointerstitial cells also show ER stress (Lindenmeyer et al. 2008), probably induced by the hyperglycemia and the massive protein reabsorption as a result of the proteinuria, but possible changes in $\left[\mathrm{Ca}^{2+}\right]_{\mathrm{ER}}$ were not investigated. The activated UPR selectively enhances the prosurvival pathway of the response, suggesting that diabetic damage may occur independently of any terminal UPR process (Brosius and Kaufman 2008).
Decreased $\mathrm{IP}_{3} \mathrm{R} 1$ expression in the afferent arteriole and mesangial cell leads to smaller $\left[\mathrm{Ca}^{2+}\right]_{\text {cyt }}$ increases in response to vasoconstrictors, resulting in renal hyperfiltration and glomerular damage (Sharma et al. 1999).

\section{Sensory Neuropathy}

Diabetic neuropathy can produce prolonged changes in the nervous system, with pain, sensory loss, food ulceration, infection, gangrene and poor wound healing (Huang et al. 2002; Verkhratsky and Fernyhough 2008). The $\left[\mathrm{Ca}^{2+}\right]_{\mathrm{ER}}$ was decreased because of a decreased SERCA expression by a so far unidentified mechanism and by a decreased activity of the pump (Verkhratsky and Fernyhough 2008). The decreased activity of SERCA may be caused by impaired mitochondrial ATP production in diabetes because of reduced stimulation of insulin receptors (Fernyhough and Calcutt 2010). This effect on the mitochondria seems to be independent of the hyperglycemia. The decreased $\left[\mathrm{Ca}^{2+}\right]_{\mathrm{ER}}$ then affects protein synthesis, posttranslational modification and trafficking, which in turn diminish the supply of voltage-gated $\mathrm{Ca}^{2+}$ channels to the axons, thus resulting in the decrease of nerve-conductance velocity (Verkhratsky and Fernyhough 2008). Stimulus-induced $\left[\mathrm{Ca}^{2+}\right]_{\text {cyt }}$ increases decrease (Kruglikov et al. 2004) as a result of the decreased $\left[\mathrm{Ca}^{2+}\right]_{\mathrm{ER}}$ and probably also as a result of decreased $\mathrm{IP}_{3} \mathrm{R}$ function. Protein glycosylation with $\beta$-N-acetylglucosamine is increased in diabetes ( $\mathrm{Hu}$ et al. 2005). Glycosylation of $\mathrm{IP}_{3} \mathrm{R} 1$ by $\beta-N$-acetylglucosamine decreases its function (Rengifo et al. 2007).

\section{Salivary Glands}

Abnormal $\mathrm{Ca}^{2+}$ signaling in the salivary glands leads to dryness of the mouth, loss of taste sensation, sialosis, and other disorders of the oral cavity (Nicolau et al. 2009). SERCA is inhibited in the submandibular gland of streptozotocininduced diabetic rats and therefore $\left[\mathrm{Ca}^{2+}\right]_{\mathrm{ER}}$ and $\mathrm{IP}_{3}$-induced $\left[\mathrm{Ca}^{2+}\right]_{\text {cyt }}$ increases decrease (Fedirko et al. 2006). The decreased $\left[\mathrm{Ca}^{2+}\right]_{\mathrm{ER}}$ results in improper posttranslational processing, folding, and exit of ER proteins. This could 
explain the decreased saliva protein content and amylase activity.

\section{NEUROLOGICAL DISEASES}

Neural Ischemia

Ischemia depletes ER $\mathrm{Ca}^{2+}$. Both the decreased $\left[\mathrm{Ca}^{2+}\right]_{\mathrm{ER}}$ (Paschen and Mengesdorf 2005) and the increased $\left[\mathrm{Ca}^{2+}\right]_{\text {cyt }}$ (Verkhratsky 2005) contribute to cell death. The induced UPR may lead to apoptosis in the peri-infarct area (DeGracia et al. 2002). The release of $\mathrm{Ca}^{2+}$ amplifies the $\left[\mathrm{Ca}^{2+}\right]_{\text {cyt }}$ increase evoked by ischemia-induced $\mathrm{Ca}^{2+}$ entry (Xiong et al. 2007). Inhibition of this release with dantrolene reduces cell injury (Wei and Perry 1996). The mechanism of ER $\mathrm{Ca}^{2+}$ depletion remains unclear. Cytosolic $\mathrm{Ca}^{2+}$ enhances NO synthesis, which inhibits mitochondrial electron transport, and augments the generation of reactive oxygen species (ROS) (Moncada and Erusalimsky 2002). SERCA becomes inhibited by excessive NO production (Doutheil et al. 2000), by ischemiainduced inhibition of the coupling of ATP hydrolysis to $\mathrm{Ca}^{2+}$ transport (Parsons et al. 1999), and by activated calpain by the increased $\left[\mathrm{Ca}^{2+}\right]_{\mathrm{cyt}}$ (French et al. 2006; Bevers and Neumar 2008). ER $\mathrm{Ca}^{2+}$-release channels are affected during neural ischemia. RyR2 is activated by $S$-glutathionylation by $\mathrm{NO}$ and ROS (Bull et al. 2008), and by calpain-induced proteolysis (Rardon et al. 1990). Calpain causes proteolysis of the $\mathrm{IP}_{3} \mathrm{R}$ resulting in decreased $\mathrm{IP}_{3}$ binding, suggesting that site-specific cleavage decreases the affinity of the remaining protein species for $\mathrm{IP}_{3}$ (Nagata et al. 1994; Dahl et al. 2000). Although this would indicate that calpain prevents $\mathrm{Ca}^{2+}$ release, it is also possible that the proteolysis simply removes the ligand regulation of the channel and leads to baseline $\mathrm{Ca}^{2+}$ release from the ER, contributing to $\mathrm{Ca}^{2+}$ overload (Bevers and Neumar 2008). Calpain also inhibits $\mathrm{IP}_{3}$ metabolism by cleaving $\mathrm{IP}_{3}$ kinase $\mathrm{B}$ (Pattni et al. 2003), allowing it to act longer on the $\mathrm{IP}_{3} \mathrm{R}$, thereby potentiating $\mathrm{Ca}^{2+}$ efflux from the ER (Bevers and Neumar 2008). Enhanced activity of phospholipase C and $\mathrm{A}_{2}$ during ischemia liberates free fatty acids, which release ER $\mathrm{Ca}^{2+}$ (O’Neil et al. 1999).

\section{Neurodegeneration}

$\mathrm{Ca}^{2+}$ signaling is often abnormal in neurodegenerative diseases (Mattson 2007). Diseases with an increased $\left[\mathrm{Ca}^{2+}\right]_{\mathrm{ER}}$, like Alzheimer disease ( Tu et al. 2006; Berridge 2010), fall outside the scope of this review. ER stress and the UPR also occur in Parkinson disease (Ryu et al. 2002), amyotrophic lateral sclerosis (Kanekura et al. 2009), and polyglutamate diseases (Lindholm et al. 2006), but the effects on $\left[\mathrm{Ca}^{2+}\right]_{\mathrm{ER}}$ are not well documented. We will focus on diseases with a decreased $\left[\mathrm{Ca}^{2+}\right]_{\mathrm{ER}}$.

Some lysosomal storage diseases lead to a decreased $\left[\mathrm{Ca}^{2+}\right]_{\mathrm{ER}}$. In neurons of $\mathrm{G}_{\mathrm{M} 1}$-gangliosidosis, $\mathrm{G}_{\mathrm{M} 1}$ accumulates at the ER membrane and depletes $\mathrm{ER} \mathrm{Ca}^{2+}$ stores (Tessitore et al. 2004) by interacting with the phosphorylated form of the $\mathrm{IP}_{3} \mathrm{R}$ (Sano et al. 2009). The subsequent activation of the UPR leads to apoptosis (Sano et al. 2009). Silencing of $\mathrm{IP}_{3} \mathrm{R} 1$ with siRNA reduces the number of apoptotic cells (Sano et al. 2009). Increased $\mathrm{Ca}^{2+}$ release from the ER in Gaucher disease is because of overactivation of the RyR (Korkotian et al. 1999; Pelled et al. 2005), because glucosylceramide, the lipid that accumulates in this disease, directly modulates the RyR (Lloyd-Evans et al. 2003). In Sandhoff disease, SERCA activity is inhibited by the accumulation of $\mathrm{G}_{\mathrm{M} 2}$-ganglioside (Pelled et al. 2003), which depends on an exposed sialic-acid residue on $\mathrm{G}_{\mathrm{M} 2}$ (Ginzburg et al. 2008). The UPR is also activated by the accumulation of palmitoylated proteins in the infantile form of Batten disease, but ER $\mathrm{Ca}^{2+}$ handling was not investigated (Zhang et al. 2007). The decreased SERCA2 and $\mathrm{IP}_{3} \mathrm{R} 1$ expression in Niemann-Pick A disease did not activate a UPR (Ginzburg and Futerman 2005). The suggestion that the UPR is a common mediator of apoptosis in neurodegenerative lysosomal storage diseases (Wei et al. 2008a) can therefore be questioned (Farfel-Becker et al. 2009). Increasing $\left[\mathrm{Ca}^{2+}\right]_{\mathrm{ER}}$ by inhibiting the RyR or by SERCA2b overexpression partially restored mutant-enzyme homeostasis in several lysosomal storage diseases (Ong et al. 2010).

Transmissible spongiform encephalopathies include Creutzfeldt-Jakob disease in humans, 
D. Mekahli et al.

and bovine spongiform encephalopathy and scrapie in animals (Prusiner 1998). These diseases are associated with extracellular accumulation of a conformationally modified abnormal isoform of the prion protein, a widely expressed plasma membrane-associated glycoprotein with highest levels of expression on neurons and glia. This protein binds to the cell surface and sends a signal to the ER to release $\mathrm{Ca}^{2+}$ through the $\mathrm{IP}_{3} \mathrm{R}$ and RyR (Hetz et al. 2003; Ferreiro et al. 2006, 2008). The subsequent decreased $\left[\mathrm{Ca}^{2+}\right]_{\mathrm{ER}}$ leads to a UPR and activates the ER-stress-induced apoptosis pathway. Dantrolene and xestospongin C, which are inhibitors of the RyR and $\mathrm{IP}_{3} \mathrm{R}$ respectively, prevent neuronal death (Ferreiro et al. 2006, 2008).

\section{Neuropathic Pain}

Neuropathic pain is pain arising from nerve injury. The soma of sensory neurons is affected by injuring the peripheral axons. Spinal-nerve ligation depletes ER $\mathrm{Ca}^{2+}$ (Rigaud et al. 2009) by a loss of ER and therefore of SERCA (Gemes et al. 2009). Rigaud et al. (2009) suggested that this may trigger a UPR, but this was not directly shown. Depletion of ER $\mathrm{Ca}^{2+}$ stores thus contributes to the pathogenesis of neuropathic pain.

\section{Anesthesia}

General anesthesia may cause cognitive deficits after surgery (Moller et al. 1998). Inhalation anesthetics can overactivate the $\mathrm{IP}_{3} \mathrm{R}$, with excessive $\mathrm{ER} \mathrm{Ca}^{2+}$ release leading to apoptosis (Wei et al. 2008b; Yang et al. 2008). Neurons with enhanced $\mathrm{IP}_{3} \mathrm{R}$ activity, for example, in familial Alzheimer or Huntington disease, may be especially vulnerable.

\section{CARDIOVASCULAR DISEASES}

\section{Atherosclerosis}

Macrophages play a critical role in this chronic inflammatory disease (Fan and Watanabe 2003). They accumulate unesterified cholesterol in advanced lesions, which changes the fluidity of the ER membrane and in this way inhibits
SERCA (Li et al. 2004). Depletion of ER $\mathrm{Ca}^{2+}$ stores induces a UPR and apoptosis (Feng et al. 2003). Excessive apoptosis plays a key role in the progression of atherosclerosis. The UPR also sets up a positive feedback loop with more $\mathrm{Ca}^{2+}$ release via induction of ER oxidase $1 \alpha$. Hyperoxidation of the ER lumen activates $\mathrm{Ca}^{2+}$ release (Li et al. 2009) by disulfide-bond formation between two cysteines in $\mathrm{IP}_{3} \mathrm{R} 1$ and dissociation of the inhibitory ERp44 (Kang et al. 2008). This mechanism complements the increased $\mathrm{ER} \mathrm{Ca}^{2+}$ leak through induction of a truncated variant of SERCA1 through the PERK pathway (Chami et al. 2008).

Homocysteine, a risk factor for cardiovascular disease, depletes ER $\mathrm{Ca}^{2+}$ in aortic smooth muscle, induces ER stress and in this way accelerates atherosclerosis (Dickhout et al. 2007). Also increased production of superoxide anion inhibits SERCA in blood vessels (Tong et al. 2009).

Endothelial dysfunction already occurs early during atherogenesis. Increased peroxynitrite formation in the endothelium inhibits SERCA, depletes ER $\mathrm{Ca}^{2+}$ and induces a UPR (Dickhout et al. 2005).

\section{Chronic Heart Failure}

Reduced $\left[\mathrm{Ca}^{2+}\right]_{\text {cyt }}$ increases caused by a decreased SR $\mathrm{Ca}^{2+}$ content make the heart muscle too weak to pump sufficient blood through the body (Bers et al. 2003). $\mathrm{Ca}^{2+}$ pumping is reduced because of a decreased ratio of SERCA2a relative to phospholamban expression (Hasenfuss and Pieske 2002), or because phospholamban is either mutated with more inhibition of SERCA2a (Franz et al. 2001; Schmitt et al. 2003; Haghighi et al. 2006; Kranias and Bers 2007) or less phosphorylated (Frank et al. 2002; Bers et al. 2003; Yano et al. 2008) because of a more active protein phosphatase 1 (del Monte and Hajjar 2008). SERCA2 mutations have not been linked to heart failure (Schmidt et al.2003a). SERCA3f, an isoform with a specific role in ER stress, becomes up-regulated (Dally et al. 2009). Enhanced $\mathrm{Na}^{+}-\mathrm{Ca}^{2+}$ exchange leading to more extrusion of $\mathrm{Ca}^{2+}$ from the cell also depletes SR Ca ${ }^{2+}$ (O'Rourke et al. 1999). 
Subconductance states of the RyR2 and decreased coupled gating of RyR2-channel clusters can increase SR $\mathrm{Ca}^{2+}$ leak during diastole (Reiken et al. 2003; Wehrens et al. 2003, 2005a, 2006; Lehnart et al. 2005, 2008; Huang et al. 2006; Zalk et al. 2007). Hyperactivation of RyR2 may arise from activated protein kinase A by sympathetic neurons and increased levels of catecholamines, and subsequent hyperphosphorylation of RyR2 at Ser-2809 and dissociation of FKBP12.6 (Marx et al. 2000) (but see Bers et al. 2003; Seidler et al. 2007; Yano et al. 2008). Enhanced $\mathrm{Ca}^{2+} /$ calmodulindependent protein kinase $\delta$-dependent phosphorylation of RyR2 at Ser-2815 also increases diastolic $\mathrm{Ca}^{2+}$ leak and reduces SR $\mathrm{Ca}^{2+}$ load (Ai et al. 2005).

ß-blockers prevent the hyperphosphorylation of RyR2 by protein kinase A, normalize channel function and improve cardiac function (Reiken et al. 2001; Doi et al. 2002). Heart failure can also be prevented by JTV519, which inhibits the dissociation of FKBP12.6 from RyR2; thereby stabilizing the channel, enhancing cooperativity among the subunits, and promoting coupled gating (Yano et al. 2003; Wehrens et al. 2005b). Overexpression of SERCA2 (Inesi et al. 2008; Kawase and Hajjar 2008), of pseudophosphorylated phospholamban (Hoshijima et al. 2002), or of FKBP12.6 (Huang et al. 2006), gene transfer of a phospholamban-targeted antibody (Dieterle et al. 2005), and down-regulation of phospholamban (Andino et al. 2008) can correct in vivo cardiac function. Modification of SERCA/phospholamban activity/expression is a promising target for remediation of cardiac disease. Indeed, a clinical trial of SERCA2a-gene therapy is initiated (Jaski et al. 2009).

\section{VIRUS INFECTION}

Complete virions or viral proteins can decrease the $\left[\mathrm{Ca}^{2+}\right]_{\mathrm{ER}}$. Some viruses stimulate $\mathrm{Ca}^{2+}$ release via the $\mathrm{IP}_{3} \mathrm{R}$, often by increasing the $\left[\mathrm{IP}_{3}\right]$ (Table 1). Other viruses release $\mathrm{Ca}^{2+}$ via an increased expression or function of the RyR. They may also decrease SERCA activity or expression, enhance the passive $\mathrm{Ca}^{2+}$ leak from the ER, or form pores in the ER membrane. Nef of human immunodeficiency virus type 1 directly interacts with the $\mathrm{IP}_{3} \mathrm{R}$ and activates $\mathrm{Ca}^{2+}$ entry, without however inducing $\mathrm{Ca}^{2+}$ release (Foti et al. 1999; Manninen and Saksela 2002).

ER $\mathrm{Ca}^{2+}$ depletion may be apoptotic or antiapoptotic, depending on the virus, its life cycle, and the induced pathology (Chami et al. 2006; Zhou et al. 2009). $\mathrm{Ca}^{2+}$ depletion by, for example, enteroviruses and human cytomegalovirus, delays apoptosis, giving the virus more time for replication. These viruses reduce ERmitochondrial $\mathrm{Ca}^{2+}$ fluxes and prevent opening of the PTP with less release of cytochrome $c$ and less caspase activation (van Kuppeveld et al. 2005; Sharon-Friling et al. 2006). ER and also Golgi $\mathrm{Ca}^{2+}$ depletion by e.g., enteroviruses leads to the accumulation of $\mathrm{ER} /$ Golgi-derived vesicles, where viral RNA replication takes place (van Kuppeveld et al. 2005), and inhibits vesicular protein trafficking and so down-regulates immune responses of the ghost (de Jong et al. 2006). In contrast, $\mathrm{ER} \mathrm{Ca}^{2+}$ depletion by hepatitis $C$ virus in liver promotes apoptosis and facilitates virion release because of translocation of Bax to the mitochondria, depolarization of the mitochondrial membrane, release of cytochrome $c$, and activation of caspase 3 (BenaliFuret et al. 2005). Abnormal $\mathrm{Ca}^{2+}$ signaling by Gp120 and Tat causes neuronal apoptosis and dysfunction and eventually AIDS dementia (Haughey and Mattson 2002). The decreased SERCA expression and increased RyR expression in Borna disease lead to ER stress, activation of the UPR and apoptotic degeneration of the cerebellum and hippocampus (Williams and Lipkin 2006). ER $\mathrm{Ca}^{2+}$ depletion also increases $\left[\mathrm{Ca}^{2+}\right]_{\text {cyt }}$ and therefore activates $\mathrm{Ca}^{2+}$ dependent enzymatic processes and transcription factors, promoting virus replication and the induction of a variety of responses.

Some antiviral drugs directly affect the $\left[\mathrm{Ca}^{2+}\right]_{\mathrm{ER}}$. Human immunodeficiency virusprotease inhibitors induce the accumulation of free cholesterol in the ER of macrophages, deplete ER $\mathrm{Ca}^{2+}$, and induce ER stress and apoptosis (Zhou et al. 2005). This may explain the increased incidence of atherosclerosis and 
D. Mekahli et al.

Table 1. Effects of complete virions or viral proteins on the $\left[\mathrm{Ca}^{2+}\right]_{E R}$.

\begin{tabular}{|c|c|c|c|}
\hline Target & Effect & Virus or viral protein & Reference \\
\hline \multirow[t]{12}{*}{$\mathrm{IP}_{3} \mathrm{R}$} & $\begin{array}{l}\text { Increased } \mathrm{IP}_{3} \mathrm{R} \\
\text { activity }\end{array}$ & $\begin{array}{l}\mathrm{p} 12^{\mathrm{I}} \text { of human T-cell } \\
\text { lymphotropic virus type } 1 \\
\text { glycoproteins of human herpes } \\
\text { simplex virus type } 1 \text { and type } 2\end{array}$ & Cheshenko et al. 2003 \\
\hline & \multirow{11}{*}{$\begin{array}{l}\text { Increased } \mathrm{IP}_{3} \mathrm{R} \\
\text { activity because } \\
\text { of increased } \mathrm{IP}_{3} \\
\text { production }\end{array}$} & influenza A virus & Hartshorn et al. 1988 \\
\hline & & Poliovirus & Guinea et al. 1989 \\
\hline & & \multirow{2}{*}{$\begin{array}{l}\text { gp120 and Tat of human } \\
\text { immunodeficiency virus type } 1\end{array}$} & Dayanithi et al. 1995 \\
\hline & & & $\begin{array}{l}\text { Mayne et al. } 2000 \\
\text { Haughey and Mattson } 2002\end{array}$ \\
\hline & & \multirow{3}{*}{$\begin{array}{l}\text { nonstructural protein } 4 \text { of } \\
\text { rotavirus }\end{array}$} & Tian et al. 1995 \\
\hline & & & Dong et al. 1997 \\
\hline & & & Seo et al. 2008 \\
\hline & & gp86 of human cytomegalovirus & Keay et al. 1995 \\
\hline & & G-protein coupled receptor and & Arvanitakis et al. 1997 \\
\hline & & viral macrophage & Nakano et al. 2003 \\
\hline & & $\begin{array}{l}\text { inflammatory protein-I and -II } \\
\text { of human herpes virus } 8\end{array}$ & \\
\hline \multirow[t]{3}{*}{ RyR } & \multirow[t]{2}{*}{$\begin{array}{l}\text { Increased RyR } \\
\text { activity }\end{array}$} & $\begin{array}{l}\text { Tat of human immunodeficiency } \\
\text { virus type } 1\end{array}$ & Norman et al. 2008 \\
\hline & & Poliovirus & Brisac et al. 2010 \\
\hline & $\begin{array}{l}\text { Increased RyR } \\
\text { expression }\end{array}$ & Borna disease virus & Williams and Lipkin 2006 \\
\hline \multirow[t]{3}{*}{ SERCA } & $\begin{array}{l}\text { Decreased SERCA } \\
\text { activity }\end{array}$ & core protein of hepatitis $\mathrm{C}$ virus & Benali-Furet et al. 2005 \\
\hline & \multirow{2}{*}{$\begin{array}{l}\text { Decreased SERCA } \\
\text { expression }\end{array}$} & Borna disease virus & Williams and Lipkin 2006 \\
\hline & & $\begin{array}{l}\text { latent membrane protein-1 of } \\
\text { Epstein-Barr virus }\end{array}$ & Dellis et al. 2009 \\
\hline Passive $\mathrm{Ca}^{2+}$ leak & $\begin{array}{l}\text { Enhanced passive } \\
\qquad \mathrm{Ca}^{2+} \text { leak }\end{array}$ & $\begin{array}{l}\text { nonstructural protein } 5 \mathrm{~A} \text { of } \\
\text { hepatitis } \mathrm{C} \text { virus }\end{array}$ & Robinson and Marchant 2008 \\
\hline \multirow[t]{8}{*}{ ER membrane } & \multirow[t]{8}{*}{ Pore formation } & \multirow{2}{*}{$\begin{array}{l}\mathrm{p} 7 \text { and core protein of hepatitis } \mathrm{C} \\
\text { virus }\end{array}$} & Griffin et al. 2003 \\
\hline & & & Bergqvist et al. 2003 \\
\hline & & \multirow{2}{*}{$\begin{array}{l}2 \mathrm{~B} \text { and } 2 \mathrm{BC} \text { proteins of entero- } \\
\text { and rhinoviruses }\end{array}$} & Aldabe et al. 1997 \\
\hline & & & de Jong et al. 2008 \\
\hline & & $\begin{array}{l}\text { nonstructural protein } 4 \text { of } \\
\text { rotavirus }\end{array}$ & Zhou et al. 2009 \\
\hline & & pUL37x1 protein of human & Sharon-Friling et al. 2006 \\
\hline & & cytomegalovirus & Zhou et al. 2009 \\
\hline & & $6 \mathrm{~K}$ protein of alphavirus & Antoine et al. 2007 \\
\hline
\end{tabular}

cardiovascular disease in patients treated with protease inhibitors. Lopinavir and ritonavir also deplete $\mathrm{ER} \mathrm{Ca}^{2+}$ and activate the UPR in intestinal epithelial cells, thus disrupting the epithelial barrier integrity with drug-induced diarrhea as a frequent side effect (Wu et al. 2010).

Bacteria can also cause ER stress. For example, Shiga toxins of Shigella dysenteriae serotype 1 and some serotypes of Escherichia coli deplete
$\mathrm{ER} \mathrm{Ca}^{2+}$ and trigger a UPR with apoptosis (Lee et al. 2008).

\section{LUNG DISEASES}

\section{Asthma}

SERCA2 in airway smooth muscle is downregulated in this chronic inflammatory disease with airway remodeling, leading to more 
Diseases with a Low ER Calcium Concentration

sustained $\left[\mathrm{Ca}^{2+}\right]_{\text {cyt }}$ increases and enhanced cell motility, proliferation and secretion (Mahn et al. 2009). Decreased SERCA expression might be caused by enhanced cytokine production during airway inflammation (Sathish et al. 2009).

ORMDL3 is a genetic risk factor associated with asthma (Moffatt et al. 2007). The gene encodes an ER protein (Hjelmqvist et al. 2002) that binds to and inhibits SERCA, leading to a decreased $\left[\mathrm{Ca}^{2+}\right]_{\mathrm{ER}}$ and an UPR (CanteroRecasens et al. 2010).

\section{Toxicity}

Chronic exposure to cadmium in humans is associated with lung, but also bone and renal damage. Cadmium stimulates the $\mathrm{IP}_{3} \mathrm{R}$ through $\mathrm{IP}_{3}$ production, and inhibits SERCA (Biagioli et al. 2008). The reduced $\left[\mathrm{Ca}^{2+}\right]_{\mathrm{ER}}$ leads to ER stress and ER-mediated apoptosis.

\section{LIVER DISEASES}

\section{Nonalcoholic Fatty Liver}

Triglycerides and free fatty acids accumulate in the liver of obese individuals. Palmitate and stearate deplete $\mathrm{ER} \mathrm{Ca}^{2+}$ stores and activate the UPR leading to cell death (Wei et al. 2009).

\section{Cholestatic Liver Disease}

Intrahepatic accumulation of bile acids induces hepatocellular injury. Glycochenodeoxycholic acid depletes ER $\mathrm{Ca}^{2+}$ and induces a UPR and apoptosis (Tsuchiya et al. 2006). It is unclear to what extent the decreasing $\left[\mathrm{Ca}^{2+}\right]_{\mathrm{ER}}$ directly contributes to the pathology.

\section{Burn Injury}

Severe burn injury impairs liver function. Thermal skin injury in rats depletes $\mathrm{ER} \mathrm{Ca}^{2+}$ in the liver (Jeschke et al. 2010). This effect is because of an activation of the $\mathrm{IP}_{3} \mathrm{R}$ by released cytochrome $c$ and an increased $\mathrm{IP}_{3} \mathrm{R}$ expression. ER $\mathrm{Ca}^{2+}$ depletion activates the UPR leading to apoptosis.

\section{SKELETAL-MUSCLE DISEASES}

\section{Brody Disease}

Mutations in the gene of SERCA1 (Odermatt et al. 1996) leading to reduced $\mathrm{Ca}^{2+}$-pump expression or activity and hence a prolonged $\left[\mathrm{Ca}^{2+}\right]_{\text {cyt }}$ elevation cause muscle cramping and impaired relaxation during exercise (Brody 1969). Chianina cattle congenital pseudomyotonia (Drogemuller et al. 2008) and Belgian Blue cattle congenital muscular dystony (Charlier et al. 2008) are related pathologies. Until now, no evidence for a UPR leading to apoptosis has been provided, but the ongoing contracture in cattle may induce rhabdomyolysis (Sacchetto et al. 2009).

\section{Autosomal Centronuclear Myopathy}

Centronuclear myopathies are characterized by small myofibers with centrally placed nuclei. Mutations of the muscle-specific inositol phosphatase MIP/MTMR14 cause the dominant form of the disease (Tosch et al. 2006; Shen et al. 2009). Mice deficient in this phosphatase produce less contractile force, have prolonged relaxation, and show exacerbated fatigue. PtdIns $(3,5) \mathrm{P}_{2}$ and $\operatorname{PtdIns}(3,4) \mathrm{P}_{2}$ accumulate and directly activate RyR1, resulting in an increased $\mathrm{Ca}^{2+}$ leak, a lower $\left[\mathrm{Ca}^{2+}\right]_{\mathrm{SR}}$ and a higher $\left[\mathrm{Ca}^{2+}\right]_{\text {cyt }}$. This proposed effect of PtdIns $(3,5) \mathrm{P}_{2}$ and PtdIns $(3,4) \mathrm{P}_{2}$ on RyR1 still needs confirmation.

\section{Central Core Disease}

Some mutations in the gene for RyR1 lead to hypotonia, proximal-muscle weakness, and central cores on muscle biopsy (Zhang et al. 1993). They can lead to a leaky channel and a reduced $\left[\mathrm{Ca}^{2+}\right]_{\mathrm{SR}}$, with deleterious consequences for contractions (Brini et al. 2005).

\section{SKIN DISEASE}

Darier disease is an inherited skin disorder with less adhesion between epidermal cells and abnormal keratinization. Mutations in the gene encoding SERCA2 (Sakuntabhai et al. 1999) lower the $\left[\mathrm{Ca}^{2+}\right]_{\mathrm{ER}}$ in keratinocytes (Foggia 
D. Mekahli et al.

et al. 2006). ER stress may occur (Onozuka et al. 2006).

The fruit hull of mangosteen is used in Southeast Asia to treat skin infections and wounds (Mahabusarakam et al. 1987). $\alpha$-mangostin inhibits SERCA, leading to a UPR and apoptosis (Sato et al. 2004).

\section{CANCER}

\section{Malignant Transformation}

Altered $\mathrm{Ca}^{2+}$ signaling may be involved in malignant transformation (Monteith et al. 2007). $\left[\mathrm{Ca}^{2+}\right]_{\mathrm{ER}}$ is often decreased, making the cell resistant to apoptosis. Subsequent $\mathrm{Ca}^{2+}$ entry increases $\left[\mathrm{Ca}^{2+}\right]_{\mathrm{cyt}}$ and changes gene expression, DNA repair, and cell-cycle regulation, resulting in cancer development (Korosec et al. 2006; Monteith et al. 2007; Lipskaia et al. 2009).

Human hepatitis B virus, an etiologic factor of hepatocellular carcinoma, integrates with its DNA into the gene for SERCA1 and cis-activates chimeric transcripts producing inactive proteins that deplete ER $\mathrm{Ca}^{2+}$ stores (Chami et al. 2000). Mice with a heterozygous deletion of the gene encoding SERCA2 (Liu et al. 2001) and some patients with Darier disease (Burge and Wilkinson 1992) develop squamous cell carcinomas. Neoplastic transformation has been linked to a down-regulated SERCA2 (Pacifico et al. 2003; Vanoverberghe et al. 2004; Bergner et al. 2009) or SERCA3 (Gelebart et al. 2002; Brouland et al. 2005), e.g., by somatic or germ-like mutations or epigenetic mechanisms involving promotor methylation (Endo et al. 2004; Korosec et al. 2006, 2008). ER Ca ${ }^{2+}$ depletion can also result from overexpression of $\mathrm{Ca}^{2+}$-release channels. $\mathrm{IP}_{3} \mathrm{R} 3$ is overexpressed in disseminated gastric cancer (Sakakura et al. 2003). The amplification of the gene for $\mathrm{IP}_{3} \mathrm{R} 2$ increases in some tumors (Heighway et al. 1996). Increased $\mathrm{IP}_{3} \mathrm{R}$ expression does not occur in all cancers (Bergner et al. 2009).

\section{Anticancer Drugs}

Most chemotherapeutic approaches kill tumor cells via the induction of MOMP. However, drugs that compromise the normal function and homeostasis of the ER may also induce programmed cell death or improve the therapeutic efficacy of existing anticancer drugs (Boelens et al. 2007). Some drugs primarily reduce the $\left[\mathrm{Ca}^{2+}\right]_{\mathrm{ER}}$ and in this way induce a UPR leading to apoptosis. Known SERCA blockers like thapsigargin and curcumin have anticancer activity (Denmeade et al. 2003; Anand et al. 2008; Bakhshi et al. 2008). Anticancer drugs like the stable analogue of the Bcl-2 antagonist HA 14-1 (Hermanson et al. 2009), artemisinin (Stockwin et al. 2009), amiloride analogues (Park et al. 2009), and 2,5-dimethyl-celecoxib (Johnson et al. 2002; Pyrko et al. 2007) also inhibit SERCA with ER stress as a result. SERCA2 expression decreases after photodynamic therapy with hypericin (Buytaert et al. 2006). ER $\mathrm{Ca}^{2+}$ stores are depleted by euplotin C through activated RyRs (Cervia et al. 2006), by paclitaxel through formation of Bax dimers in the ER (Liao et al. 2008), and by epigallocatechin gallate through inhibited protein processing at the level of glucosidase II (Magyar et al. 2009) and GRP78/BiP (Ermakova et al. 2006). $\mathrm{Ca}^{2+}$ depletion and ER stress are also induced by cisplatin (Nawrocki et al. 2005), dehydrocostuslactone (Hsu et al. 2009; Hung et al. 2010), honokiol (Chen et al. 2010), diaryl- and triarylmethanes (Abdelrahim et al. 2006), inhibitors of heat shock protein 90 (Taiyab et al. 2009), n-3 long-chain polyunsaturated fatty acids (Jakobsen et al. 2008), rhein (Lai et al. 2009), cardiotoxin III (Chien et al. 2008), homoharringtonine (Jie et al. 2007), berberine (Lin et al. 2007b), diindolylmethane (Savino et al. 2006), the multi-kinase inhibitor sorafenib (Rahmani et al. 2007), the p210 bcr-abl tyrosine-kinase inhibitor STI571 (Pattacini et al. 2004), parthenolide (Zhang et al. 2004), photodynamic therapy with tetra-S-glycosylated porphyrin (Thompson et al. 2008), and by many other drugs. Edelfosine leads to Bax/ Bak-mediated ER $\mathrm{Ca}^{2+}$ depletion and apoptosis, without inducing a UPR (Nieto-Miguel et al. 2007).

$\mathrm{Ca}^{2+}$ depletion-induced ER stress can also lead to autophagy, for example, in response to the tyrosine-kinase inhibitor imatinib (Bellodi et al. 2009), or to necrosis, for example, in 
therapy-resistant tumors with down-regulated Bax or Bak (Janssen et al. 2009).

\section{CONCLUDING REMARKS}

Depletion of ER $\mathrm{Ca}^{2+}$ occurs in many diseases. The accompanying ER stress often triggers a UPR leading to apoptosis. The release of insufficient activator $\mathrm{Ca}^{2+}$ may compromise essential cell functions. We now begin to understand the molecular mechanisms that reduce the ER $\mathrm{Ca}^{2+}$ content. Some therapies already directly target the $\mathrm{Ca}^{2+}$-signaling pathway. A better understanding of the defective $\mathrm{Ca}^{2+}$ signal and the development of better drugs targeting the proteins involved will eventually result in better treatments for these various diseases.

\section{ACKNOWLEDGMENTS}

Work performed in our laboratory was supported by grants from the Research Foundation-Flanders, the Concerted Actions of the K.U.Leuven, and the Interuniversity Attraction Poles Programme.

\section{REFERENCES}

Abdelrahim M, Newman K, Vanderlaag K, Samudio I, Safe S. 2006. 3,3'-diindolylmethane (DIM) and its derivatives induce apoptosis in pancreatic cancer cells through endoplasmic reticulum stress-dependent upregulation of DR5. Carcinogenesis 27: 717-728.

Adachi T, Weisbrod RM, Pimentel DR, Ying J, Sharov VS, Schoneich C, Cohen RA. 2004. S-glutathiolation by peroxynitrite activates SERCA during arterial relaxation by nitric oxide. Nat Med 10: 1200-1207.

Ai X, Curran JW, Shannon TR, Bers DM, Pogwizd SM. 2005. $\mathrm{Ca}^{2+} /$ calmodulin-dependent protein kinase modulates cardiac ryanodine receptor phosphorylation and sarcoplasmic reticulum $\mathrm{Ca}^{2+}$ leak in heart failure. Circ Res 97: 1314-1322.

Akerfeldt MC, Howes J, Chan JY, Stevens VA, Boubenna N, McGuire HM, King C, Biden TJ, Laybutt DR. 2008. Cytokine-induced $\beta$-cell death is independent of endoplasmic reticulum stress signaling. Diabetes 57: 30343044.

Aldabe R, Irurzun A, Carrasco L. 1997. Poliovirus protein 2BC increases cytosolic free calcium concentrations. $J$ Virol 71: 6214-6217.

Almind K, Bjorbaek C, Vestergaard H, Hansen T, Echwald S, Pedersen O. 1993. Aminoacid polymorphisms of insulin receptor substrate-1 in non-insulin-dependent diabetes mellitus. Lancet 342: 828-832.

Anand P, Sundaram C, Jhurani S, Kunnumakkara AB, Aggarwal BB. 2008. Curcumin and cancer: an "old-age" disease with an "age-old" solution. Cancer Lett 267: 133-164.

Andino LM, Takeda M, Kasahara H, Jakymiw A, Byrne BJ, Lewin AS. 2008. AAV-mediated knockdown of phospholamban leads to improved contractility and calcium handling in cardiomyocytes. J Gene Med 10: 132-142.

Antoine AF, Montpellier C, Cailliau K, Browaeys-Poly E, Vilain JP, Dubuisson J. 2007. The $\alpha$ virus $6 \mathrm{~K}$ protein activates endogenous ionic conductances when expressed in Xenopus oocytes. J Membr Biol 215: 37-48.

Araki E, Oyadomari S, Mori M. 2003. Impact of endoplasmic reticulum stress pathway on pancreatic $\beta$-cells and diabetes mellitus. Exp Biol Med 228: 1213-1217.

Arredouani A, Guiot Y, Jonas JC, Liu LH, Nenquin M, Pertusa JA, Rahier J, Rolland JF, Shull GE, Stevens M, et al. 2002. SERCA3 ablation does not impair insulin secretion but suggests distinct roles of different sarcoendoplasmic reticulum $\mathrm{Ca}^{2+}$ pumps for $\mathrm{Ca}^{2+}$ homeostasis in pancreatic $\beta$-cells. Diabetes 51: 3245-3253.

Arvanitakis L, Geras-Raaka E, Varma A, Gershengorn MC, Cesarman E. 1997. Human herpesvirus KSHV encodes a constitutively active G-protein-coupled receptor linked to cell proliferation. Nature 385: 347-350.

Austin RC. 2009. The unfolded protein response in health and disease. Antioxid Redox Signal 11: 2279-2287.

Bakhshi J, Weinstein L, Poksay KS, Nishinaga B, Bredesen DE, Rao RV. 2008. Coupling endoplasmic reticulum stress to the cell death program in mouse melanoma cells: effect of curcumin. Apoptosis 13: 904-914.

Beard NA, Laver DR, Dulhunty AF. 2004. Calsequestrin and the calcium release channel of skeletal and cardiac muscle. Prog Biophys Mol Biol 85: 33-69.

Belke DD, Swanson EA, Dillmann WH. 2004. Decreased sarcoplasmic reticulum activity and contractility in diabetic $\mathrm{db} / \mathrm{db}$ mouse heart. Diabetes 53: 3201-3208.

Bellodi C, Lidonnici MR, Hamilton A, Helgason GV, Soliera AR, Ronchetti M, Galavotti S, Young KW, Selmi T, Yacobi $\mathrm{R}$, et al. 2009. Targeting autophagy potentiates tyrosine kinase inhibitor-induced cell death in Philadelphia chromosome-positive cells, including primary CML stem cells. J Clin Invest 119: 1109-1123.

Belmont PJ, Tadimalla A, Chen WJ, Martindale JJ, Thuerauf DJ, Marcinko M, Gude N, Sussman MA, Glembotski CC. 2008. Coordination of growth and endoplasmic reticulum stress signaling by regulator of calcineurin 1 (RCAN1), a novel ATF6-inducible gene. J Biol Chem 283: 14012-14021.

Benali-Furet NL, Chami M, Houel L, De Giorgi F, Vernejoul F, Lagorce D, Buscail L, Bartenschlager R, Ichas F, Rizzuto $\mathrm{R}$, et al. 2005. Hepatitis $\mathrm{C}$ virus core triggers apoptosis in liver cells by inducing ER stress and ER calcium depletion. Oncogene 24: 4921-4933.

Bencsik P, Kupai K, Giricz Z, Gorbe A, Huliak I, Furst S, Dux L, Csont T, Jancso G, Ferdinandy P. 2008. Cardiac capsaicin-sensitive sensory nerves regulate myocardial relaxation via $S$-nitrosylation of SERCA: role of peroxynitrite. Br J Pharmacol 153: 488-496. 
D. Mekahli et al.

Bergner A, Kellner J, Tufman A, Huber RM. 2009. Endoplasmic reticulum $\mathrm{Ca}^{2+}$-homeostasis is altered in small and non-small cell lung cancer cell lines. J Exp Clin Cancer Res 28: 25. doi:101186/1756-9966-28-25.

Bergqvist A, Sundstrom S, Dimberg LY, Gylfe E, Masucci MG. 2003. The hepatitis $C$ virus core protein modulates $\mathrm{T}$ cell responses by inducing spontaneous and altering T-cell receptor-triggered $\mathrm{Ca}^{2+}$ oscillations. J Biol Chem 278: $18877-18883$.

Bernales S, McDonald KL, Walter P. 2006. Autophagy counterbalances endoplasmic reticulum expansion during the unfolded protein response. PLoS Biol 4: e423. doi:101371/journalpbio0040423.

Berridge MJ. 2002. The endoplasmic reticulum: a multifunctional signaling organelle. Cell Calcium 32: 235-249.

Berridge MJ. 2010. Calcium hypothesis of Alzheimer's disease. Pflugers Arch 459: 441-449.

Berridge MJ, Lipp P, Bootman MD. 2000. The versatility and universality of calcium signalling. Nat Rev Mol Cell Biol 1: $11-21$.

Bers DM, Eisner DA, Valdivia HH. 2003. Sarcoplasmic reticulum $\mathrm{Ca}^{2+}$ and heart failure: roles of diastolic leak and $\mathrm{Ca}^{2+}$ transport. Circ Res 93: 487-490.

Bevers MB, Neumar RW. 2008. Mechanistic role of calpains in postischemic neurodegeneration. J Cereb Blood Flow Metab 28: 655-673.

Bezprozvanny I. 2009. Calcium signaling and neurodegenerative diseases. Trends Mol Med 15: 89-100.

Biagioli M, Pifferi S, Ragghianti M, Bucci S, Rizzuto R, Pinton P. 2008. Endoplasmic reticulum stress and alteration in calcium homeostasis are involved in cadmiuminduced apoptosis. Cell Calcium 43: 184-195.

Bidasee KR, Nallani K, Besch HR Jr, Dincer UD. 2003a. Streptozotocin-induced diabetes increases disulfide bond formation on cardiac ryanodine receptor (RyR2). J Pharmacol Exp Ther 305: 989-998.

Bidasee KR, Nallani K, Yu Y, Cocklin RR, Zhang Y, Wang M, Dincer UD, Besch HR Jr. 2003b. Chronic diabetes increases advanced glycation end products on cardiac ryanodine receptors/calcium-release channels. Diabetes 52: $1825-1836$.

Bidasee KR, Zhang Y, Shao CH, Wang M, Patel KP, Dincer UD, Besch HR Jr. 2004. Diabetes increases formation of advanced glycation end products on sarco(endo)plasmic reticulum $\mathrm{Ca}^{2+}$-ATPase. Diabetes 53: 463-473.

Bidaud I, Mezghrani A, Swayne LA, Monteil A, Lory P. 2006. Voltage-gated calcium channels in genetic diseases. Biochim Biophys Acta 1763: 1169-1174.

Blayney LM, Lai FA. 2009. Ryanodine receptor-mediated arrhythmias and sudden cardiac death. Pharmacol Ther 123: $151-177$

Boelens J, Lust S, Offner F, Bracke ME, Vanhoecke BW. 2007. The endoplasmic reticulum: a target for new anticancer drugs. In Vivo 21: 215-226.

Borge PD Jr, Wolf BA. 2003. Insulin receptor substrate 1 regulation of sarco-endoplasmic reticulum calcium ATPase 3 in insulin-secreting $\beta$-cells. J Biol Chem 278: 11359-11368.

Bosanac I, Michikawa T, Mikoshiba K, Ikura M. 2004. Structural insights into the regulatory mechanism of $\mathrm{IP}_{3}$ receptor. Biochim Biophys Acta 1742: 89-102.
Brandman O, Liou J, Park WS, Meyer T. 2007. STIM2 is a feedback regulator that stabilizes basal cytosolic and endoplasmic reticulum $\mathrm{Ca}^{2+}$ levels. Cell 131: 1327-1339.

Brini M, Carafoli E. 2009. Calcium pumps in health and disease. Physiol Rev 89: 1341-1378.

Brini M, Manni S, Pierobon N, Du GG, Sharma P, MacLennan DH, Carafoli E. 2005. $\mathrm{Ca}^{2+}$ signaling in HEK-293 and skeletal muscle cells expressing recombinant ryanodine receptors harboring malignant hyperthermia and central core disease mutations. J Biol Chem 280: $15380-15389$.

Brisac C, Teoule F, Autret A, Pelletier I, Colbere-Garapin F, Brenner C, Lemaire C, Blondel B. 2010. Calcium flux between the endoplasmic reticulum and mitochondria contributes to poliovirus-induced apoptosis. J Virol 84: $12226-12235$.

Brody IA. 1969. Muscle contracture induced by exercise: a syndrome attributable to decreased relaxing factor. N Engl J Med 281: 187-192.

Brosius FC III, Kaufman RJ. 2008. Is the ER stressed out in diabetic kidney disease? J Am Soc Nephrol 19: 2040-2042.

Brouland JP, Gelebart P, Kovacs T, Enouf J, Grossmann J, Papp B. 2005. The loss of sarco/endoplasmic reticulum calcium transport ATPase 3 expression is an early event during the multistep process of colon carcinogenesis. Am J Pathol 167: 233-242.

Brunelle JK, Letai A. 2009. Control of mitochondrial apoptosis by the Bcl-2 family. J Cell Sci 122: 437-441.

Bull R, Finkelstein JP, Galvez J, Sanchez G, Donoso P, Behrens MI, Hidalgo C. 2008. Ischemia enhances activation by $\mathrm{Ca}^{2+}$ and redox modification of ryanodine receptor channels from rat brain cortex. J Neurosci 28: 9463-9472.

Burge SM, Wilkinson JD. 1992. Darier-White disease: a review of the clinical features in 163 patients. $J \mathrm{Am}$ Acad Dermatol 27: 40-50.

Buytaert E, Callewaert G, Hendrickx N, Scorrano L, Hartmann D, Missiaen L, Vandenheede JR, Heirman I, Grooten J, Agostinis P. 2006. Role of endoplasmic reticulum depletion and multidomain proapoptotic BAX and BAK proteins in shaping cell death after hypericinmediated photodynamic therapy. FASEB J 20: 756-758.

Cahalan MD. 2009. STIMulating store-operated $\mathrm{Ca}^{2+}$ entry. Nat Cell Biol 11: 669-677.

Cantero-Recasens G, Fandos C, Rubio-Moscardo F, Valverde MA, Vicente R. 2010. The asthma-associated ORMDL3 gene product regulates endoplasmic reticulum-mediated calcium signaling and cellular stress. Hum Mol Genet 19: 111-121.

Cardozo AK, Ortis F, Storling J, Feng YM, Rasschaert J, Tonnesen M, Van Eylen F, Mandrup-Poulsen T, Herchuelz A, Eizirik DL. 2005. Cytokines down-regulate the sarcoendoplasmic reticulum pump $\mathrm{Ca}^{2+}$ ATPase $2 \mathrm{~b}$ and deplete endoplasmic reticulum $\mathrm{Ca}^{2+}$, leading to induction of endoplasmic reticulum stress in pancreatic $\beta$-cells. Diabetes 54: 452-461.

Cervia D, Martini D, Garcia-Gil M, Di Giuseppe G, Guella G, Dini F, Bagnoli P. 2006. Cytotoxic effects and apoptotic signalling mechanisms of the sesquiterpenoid euplotin C, a secondary metabolite of the marine ciliate Euplotes crassus, in tumour cells. Apoptosis 11: 829-843. 
Chaabane C, Corvazier E, Bredoux R, Dally S, Raies A, Villemain A, Dupuy E, Enouf J, Bobe R. 2006. Sarco/ endoplasmic reticulum $\mathrm{Ca}^{2+}$ ATPase type 3 isoforms (SERCA3b and SERCA3f): distinct roles in cell adhesion and ER stress. Biochem Biophys Res Commun 345: 1377-1385.

Chaabane C, Dally S, Corvazier E, Bredoux R, Bobe R, Ftouhi B, Raies A, Enouf J. 2007. Platelet PMCA- and SERCA-type $\mathrm{Ca}^{2+}$-ATPase expression in diabetes: a novel signature of abnormal megakaryocytopoiesis. J Thromb Haemost 5: 2127-2135.

Chami M, Oules B, Paterlini-Brechot P. 2006. Cytobiological consequences of calcium-signaling alterations induced by human viral proteins. Biochim Biophys Acta 1763: $1344-1362$.

Chami M, Gozuacik D, Saigo K, Capiod T, Falson P, Lecoeur $\mathrm{H}$, Urashima T, Beckmann J, Gougeon ML, Claret M, et al. 2000. Hepatitis B virus-related insertional mutagenesis implicates SERCA1 gene in the control of apoptosis. Oncogene 19: 2877-2886.

Chami M, Oules B, Szabadkai G, Tacine R, Rizzuto R, Paterlini-Brechot P. 2008. Role of SERCA1 truncated isoform in the proapoptotic calcium transfer from ER to mitochondria during ER stress. Mol Cell 32: 641-651.

Charlier C, Coppieters W, Rollin F, Desmecht D, Agerholm JS, Cambisano N, Carta E, Dardano S, Dive M, Fasquelle C, et al. 2008. Highly effective SNP-based association mapping and management of recessive defects in livestock. Nat Genet 40: 449-454

Chen Y, Liu CP, Xu KF, Mao XD, Lu YB, Fang L, Yang JW, Liu C. 2008. Effect of taurine-conjugated ursodeoxycholic acid on endoplasmic reticulum stress and apoptosis induced by advanced glycation end products in cultured mouse podocytes. Am J Nephrol 28: 1014-1022.

Chen YJ, Wu CL, Liu JF, Fong YC, Hsu SF, Li TM, Su YC, Liu SH, Tang CH. 2010. Honokiol induces cell apoptosis in human chondrosarcoma cells through mitochondrial dysfunction and endoplasmic reticulum stress. Cancer Lett 291: 20-30.

Cheshenko N, Del Rosario B, Woda C, Marcellino D, Satlin LM, Herold BC. 2003. Herpes simplex virus triggers activation of calcium-signaling pathways. J Cell Biol 163: 283-293.

Chien CM, Yang SH, Chang LS, Lin SR. 2008. Involvement of both endoplasmic reticulum- and mitochondria-dependent pathways in cardiotoxin III-induced apoptosis in HL-60 cells. Clin Exp Pharmacol Physiol 35: $1059-1064$.

Chipuk JE, Green DR. 2008. How do BCL-2 proteins induce mitochondrial outer membrane permeabilization? Trends Cell Biol 18: 157-164.

Choi KM, Zhong Y, Hoit BD, Grupp IL, Hahn H, Dilly KW, Guatimosim S, Lederer WJ, Matlib MA. 2002. Defective intracellular $\mathrm{Ca}^{2+}$ signaling contributes to cardiomyopathy in type 1 diabetic rats. Am J Physiol 283: H1398H1408.

Clark RJ, McDonough PM, Swanson E, Trost SU, Suzuki M, Fukuda M, Dillmann WH. 2003. Diabetes and the accompanying hyperglycemia impairs cardiomyocyte calcium cycling through increased nuclear O-GlcNAcylation. J Biol Chem 278: 44230-44237.
Cooper ME, Bonnet F, Oldfield M, Jandeleit-Dahm K. 2001. Mechanisms of diabetic vasculopathy: an overview. Am J Hypert 14: 475-486.

Cunha DA, Hekerman P, Ladriere L, Bazarra-Castro A, Ortis F, Wakeham MC, Moore F, Rasschaert J, Cardozo AK, Bellomo E, et al. 2008. Initiation and execution of lipotoxic ER stress in pancreatic $\beta$-cells. J Cell Sci 121: 2308-2318.

Dahl C, Haug LS, Spilsberg B, Johansen J, Ostvold AC, Diemer NH. 2000. Reduced $\left[{ }^{3} \mathrm{H}\right] \mathrm{IP}_{3}$ binding but unchanged $\mathrm{IP}_{3}$ receptor levels in the rat hippocampus CAl region following transient global ischemia and tolerance induction. Neurochem Int 36: 379-388.

Dally S, Monceau V, Corvazier E, Bredoux R, Raies A, Bobe R, del Monte F, Enouf J. 2009. Compartmentalized expression of three novel sarco/endoplasmic reticulum $\mathrm{Ca}^{2+}$ ATPase 3 isoforms including the switch to ER stress, SERCA3f, in non-failing and failing human heart. Cell Calcium 45: 144-154.

Dayanithi G, Yahi N, Baghdiguian S, Fantini J. 1995. Intracellular calcium release induced by human immunodeficiency virus type 1 (HIV-1) surface envelope glycoprotein in human intestinal epithelial cells: a putative mechanism for HIV-1 enteropathy. Cell Calcium 18: 9-18.

DeGracia DJ, Kumar R, Owen CR, Krause GS, White BC. 2002. Molecular pathways of protein synthesis inhibition during brain reperfusion: implications for neuronal survival or death. J Cereb Blood Flow Metab 22: 127-141.

de Jong AS, de Mattia F, Van Dommelen MM, Lanke K, Melchers WJ, Willems PH, van Kuppeveld FJ. 2008. Functional analysis of picornavirus $2 \mathrm{~B}$ proteins: effects on calcium homeostasis and intracellular protein trafficking. J Virol 82: 3782-3790.

de Jong AS, Visch HJ, de Mattia F, van Dommelen MM, Swarts HG, Luyten T, Callewaert G, Melchers WJ, Willems PH, van Kuppeveld FJ. 2006. The coxsackievirus $2 \mathrm{~B}$ protein increases efflux of ions from the endoplasmic reticulum and Golgi, thereby inhibiting protein trafficking through the Golgi. J Biol Chem 281: 14144-14150.

Dellis O, Arbabian A, Brouland JP, Kovacs T, Rowe M, Chomienne C, Joab I, Papp B. 2009. Modulation of B-cell endoplasmic reticulum calcium homeostasis by EpsteinBarr virus latent membrane protein-1. Mol Cancer 8: 59. doi:101186/1476-4598-8-59.

del Monte F, Hajjar RJ. 2008. Intracellular devastation in heart failure. Heart Fail Rev 13: 151-162.

Deng X, Wang Y, Zhou Y, Soboloff J, Gill DL. 2009. STIM and Orai: dynamic intermembrane coupling to control cellular calcium signals. J Biol Chem 284: 22501-22505.

Denmeade SR, Jakobsen CM, Janssen S, Khan SR, Garrett ES, Lilja H, Christensen SB, Isaacs JT. 2003. Prostatespecific antigen-activated thapsigargin prodrug as targeted therapy for prostate cancer. J Natl Cancer Inst 95: 990-1000.

Dickhout JG, Sood SK, Austin RC. 2007. Role of endoplasmic reticulum calcium disequilibria in the mechanism of homocysteine-induced ER stress. Antioxid Redox Signal 9: $1863-1873$.

Dickhout JG, Hossain GS, Pozza LM, Zhou J, Lhotak S, Austin RC. 2005. Peroxynitrite causes endoplasmic reticulum stress and apoptosis in human vascular endothelium: implications in atherogenesis. Arterioscler Thromb Vasc Biol 25: 2623-2629. 
D. Mekahli et al.

Dieterle T, Meyer M, Gu Y, Belke DD, Swanson E, Iwatate M, Hollander J, Peterson KL, Ross J Jr, Dillmann WH. 2005. Gene transfer of a phospholamban-targeted antibody improves calcium handling and cardiac function in heart failure. Cardiovasc Res 67: 678-688.

Ding W, Albrecht B, Kelley RE, Muthusamy N, Kim SJ, Altschuld RA, Lairmore MD. 2002. Human T-cell lymphotropic virus type $1 \mathrm{p} 12^{\mathrm{I}}$ expression increases cytoplasmic calcium to enhance the activation of nuclear factor of activated T cells. J Virol 76: 10374-10382.

Doi M, Yano M, Kobayashi S, Kohno M, Tokuhisa T, Okuda S, Suetsugu M, Hisamatsu Y, Ohkusa T, Kohno M, et al. 2002. Propranolol prevents the development of heart failure by restoring FKBP12.6-mediated stabilization of ryanodine receptor. Circulation 105: 1374-1379.

Dong Y, Zeng CQ, Ball JM, Estes MK, Morris AP. 1997. The rotavirus enterotoxin NSP4 mobilizes intracellular calcium in human intestinal cells by stimulating phospholipase C-mediated inositol 1,4,5-trisphosphate production. Proc Natl Acad Sci 94: 3960-3965.

Doutheil J, Althausen S, Treiman M, Paschen W. 2000. Effect of nitric oxide on endoplasmic reticulum calcium homeostasis, protein synthesis and energy metabolism. Cell Calcium 27: 107-115.

Drogemuller C, Drogemuller M, Leeb T, Mascarello F, Testoni S, Rossi M, Gentile A, Damiani E, Sacchetto R. 2008. Identification of a missense mutation in the bovine ATP2A1 gene in congenital pseudomyotonia of Chianina cattle: an animal model of human Brody disease. Genomics 92: 474-477.

Durham WJ, Wehrens XH, Sood S, Hamilton SL. 2007. Diseases associated with altered ryanodine receptor activity. Subcell Biochem 45: 273-321.

Dutta K, Carmody MW, Cala SE, Davidoff AJ. 2002. Depressed PKA activity contributes to impaired SERCA function and is linked to the pathogenesis of glucose-induced cardiomyopathy. J Mol Cell Cardiol 34: 985-996.

Egger L, Schneider J, Rheme C, Tapernoux M, Hacki J, Borner C. 2003. Serine proteases mediate apoptosis-like cell death and phagocytosis under caspase-inhibiting conditions. Cell Death Differ 10: 1188-1203.

Eizirik DL, Cardozo AK, Cnop M. 2008. The role for endoplasmic reticulum stress in diabetes mellitus. Endocr Rev 29: $42-61$

Endo M. 2009. Calcium-induced calcium release in skeletal muscle. Physiol Rev 89: 1153-1176.

Endo Y, Uzawa K, Mochida Y, Shiiba M, Bukawa H, Yokoe H, Tanzawa H. 2004. Sarcoendoplasmic reticulum $\mathrm{Ca}^{2+}$ ATPase type 2 downregulated in human oral squamous cell carcinoma. Int J Cancer 110: 225-231.

Ermakova SP, Kang BS, Choi BY, Choi HS, Schuster TF, Ma WY, Bode AM, Dong Z. 2006. (-)-Epigallocatechin gallate overcomes resistance to etoposide-induced cell death by targeting the molecular chaperone glucose-regulated protein 78. Cancer Res 66: 9260-9269.

Evans-Molina C, Robbins RD, Kono T, Tersey SA, Vestermark GL, Nunemaker CS, Garmey JC, Deering TG, Keller SR, Maier B, et al. 2009. Peroxisome proliferatoractivated receptor $\gamma$ activation restores islet function in diabetic mice through reduction of endoplasmic reticulum stress and maintenance of euchromatin structure. Mol Cell Biol 29: 2053-2067.

Fan J, Watanabe T. 2003. Inflammatory reactions in the pathogenesis of atherosclerosis. J Atheroscler Thromb 10: $63-71$.

Farfel-Becker T, Vitner E, Dekel H, Leshem N, Enquist IB, Karlsson S, Futerman AH. 2009. No evidence for activation of the unfolded protein response in neuronopathic models of Gaucher disease. Hum Mol Genet 18: 1482-1488.

Fedirko NV, Kruglikov IA, Kopach OV, Vats JA, Kostyuk PG, Voitenko NV. 2006. Changes in functioning of rat submandibular salivary gland under streptozotocin-induced diabetes are associated with alterations of $\mathrm{Ca}^{2+}$ signaling and $\mathrm{Ca}^{2+}$ transporting pumps. Biochim Biophys Acta 1762: 294-303.

Feng B, Yao PM, Li Y, Devlin CM, Zhang D, Harding HP, Sweeney M, Rong JX, Kuriakose G, Fisher EA, et al. 2003. The endoplasmic reticulum is the site of cholesterol-induced cytotoxicity in macrophages. Nat Cell Biol 5: 781-792.

Fernyhough P, Calcutt NA. 2010. Abnormal calcium homeostasis in peripheral neuropathies. Cell Calcium 47: $130-139$.

Ferreiro E, Resende R, Costa R, Oliveira CR, Pereira CM. 2006. An endoplasmic-reticulum-specific apoptotic pathway is involved in prion and amyloid- $\beta$ peptides neurotoxicity. Neurobiol Dis 23: 669-678.

Ferreiro E, Costa R, Marques S, Cardoso SM, Oliveira CR, Pereira CM. 2008. Involvement of mitochondria in endoplasmic reticulum stress-induced apoptotic cell death pathway triggered by the prion peptide $\operatorname{PrP}(106-126)$. J Neurochem 104: 766-776.

Foggia L, Hovnanian A. 2004. Calcium pump disorders of the skin. Am J Med Genet C 131C: $20-31$.

Foggia L, Aronchik I, Aberg K, Brown B, Hovnanian A, Mauro TM. 2006. Activity of the hSPCA1 Golgi $\mathrm{Ca}^{2+}$ pump is essential for $\mathrm{Ca}^{2+}$-mediated $\mathrm{Ca}^{2+}$ response and cell viability in Darier disease. J Cell Sci 119: 671-679.

Fonseca SG, Ishigaki S, Oslowski CM, Lu S, Lipson KL, Ghosh R, Hayashi E, Ishihara H, Oka Y, Permutt MA, et al. 2010. Wolfram syndrome 1 gene negatively regulates ER stress signaling in rodent and human cells. J Clin Invest 120: 744-755.

Foskett JK, White C, Cheung KH, Mak DO. 2007. Inositol trisphosphate receptor $\mathrm{Ca}^{2+}$ release channels. Physiol Rev 87: 593-658.

Foti M, Cartier L, Piguet V, Lew DP, Carpentier JL, Trono D, Krause KH. 1999. The HIV Nef protein alters $\mathrm{Ca}^{2+}$ signaling in myelomonocytic cells through SH3-mediated protein-protein interactions. J Biol Chem 274: 3476534772.

Frank KF, Bolck B, Brixius K, Kranias EG, Schwinger RH. 2002. Modulation of SERCA: implications for the failing human heart. Basic Res Cardiol 97: I72-I78.

Franz WM, Muller OJ, Katus HA. 2001. Cardiomyopathies: from genetics to the prospect of treatment. Lancet 358: $1627-1637$.

French JP, Quindry JC, Falk DJ, Staib JL, Lee Y, Wang KK, Powers SK. 2006. Ischemia-reperfusion-induced calpain 
activation and SERCA2a degradation are attenuated by exercise training and calpain inhibition. Am J Physiol 290: H128-H136.

Gaut JR, Hendershot LM. 1993. The modification and assembly of proteins in the endoplasmic reticulum. Curr Opin Cell Biol 5: 589-595.

Gelebart P, Kovacs T, Brouland JP, van Gorp R, Grossmann J, Rivard N, Panis Y, Martin V, Bredoux R, Enouf J, et al. 2002. Expression of endomembrane calcium pumps in colon and gastric cancer cells. Induction of SERCA3 expression during differentiation. I Biol Chem 277: 26310-26320.

Gemes G, Rigaud M, Weyker PD, Abram SE, Weihrauch D, Poroli M, Zoga V, Hogan QH. 2009. Depletion of calcium stores in injured sensory neurons: anatomic and functional correlates. Anesthesiology 111: 393-405.

Ginzburg L, Futerman AH. 2005. Defective calcium homeostasis in the cerebellum in a mouse model of NiemannPick A disease. J Neurochem 95: 1619-1628.

Ginzburg L, Li SC, Li YT, Futerman AH. 2008. An exposed carboxyl group on sialic acid is essential for gangliosides to inhibit calcium uptake via the sarco/endoplasmic reticulum $\mathrm{Ca}^{2+}$-ATPase: relevance to gangliosidoses. $J$ Neurochem 104: 140-146.

Giorgi C, De Stefani D, Bononi A, Rizzuto R, Pinton P. 2009. Structural and functional link between the mitochondrial network and the endoplasmic reticulum. Int J Biochem Cell Biol 41: 1817-1827.

Giorgi C, Romagnoli A, Pinton P, Rizzuto R. 2008. $\mathrm{Ca}^{2+}$ signaling, mitochondria and cell death. Curr Mol Med 8: 119-130.

Gotoh T, Mori M. 2006. Nitric oxide and endoplasmic reticulum stress. Arterioscler Thromb Vasc Biol 26: 1439-1446.

Griffin SD, Beales LP, Clarke DS, Worsfold O, Evans SD, Jaeger J, Harris MP, Rowlands DJ. 2003. The p7 protein of hepatitis $\mathrm{C}$ virus forms an ion channel that is blocked by the antiviral drug, Amantadine. FEBS Lett 535: 34-38.

Grover AK, Kwan CY, Samson SE. 2003. Effects of peroxynitrite on sarco/endoplasmic reticulum $\mathrm{Ca}^{2+}$ pump isoforms SERCA2b and SERCA3a. Am J Physiol 285: C1537-C1543.

Guest PC, Bailyes EM, Hutton JC. 1997. Endoplasmic reticulum $\mathrm{Ca}^{2+}$ is important for the proteolytic processing and intracellular transport of proinsulin in the pancreatic ß-cell. Biochem J 323: 445-450.

Guinea R, Lopez-Rivas A, Carrasco L. 1989. Modification of phospholipase $\mathrm{C}$ and phospholipase $\mathrm{A} 2$ activities during poliovirus infection. J Biol Chem 264: 21923-21927.

Guner S, Arioglu E, Tay A, Tasdelen A, Aslamaci S, Bidasee KR, Dincer UD. 2004. Diabetes decreases mRNA levels of calcium-release channels in human atrial appendage. Mol Cell Biochem 263: 143-150.

Gurzov EN, Ortis F, Cunha DA, Gosset G, Li M, Cardozo AK, Eizirik DL. 2009. Signaling by IL- $1 \beta+$ IFN- $\gamma$ and ER stress converge on DP5/Hrk activation: a novel mechanism for pancreatic $\beta$-cell apoptosis. Cell Death Differ 16: $1539-1550$.

Gwiazda KS, Yang TL, Lin Y, Johnson JD. 2009. Effects of palmitate on ER and cytosolic $\mathrm{Ca}^{2+}$ homeostasis in $\beta$-cells. Am J Physiol 296: E690-E701.
Gyorke S. 2009. Molecular basis of catecholaminergic polymorphic ventricular tachycardia. Heart Rhythm 6: $123-129$.

Gyorke S, Terentyev D. 2008. Modulation of ryanodine receptor by luminal calcium and accessory proteins in health and cardiac disease. Cardiovasc Res 77: 245-255.

Haghighi K, Kolokathis F, Gramolini AO, Waggoner JR, Pater L, Lynch RA, Fan GC, Tsiapras D, Parekh RR, Dorn GW II, et al. 2006. A mutation in the human phospholamban gene, deleting arginine 14, results in lethal, hereditary cardiomyopathy. Proc Natl Acad Sci 103: $1388-1393$.

Han I, Kudlow JE. 1997. Reduced O glycosylation of Sp1 is associated with increased proteasome susceptibility. Mol Cell Biol 17: 2550-2558.

Harding HP, Zhang Y, Ron D. 1999. Protein translation and folding are coupled by an endoplasmic-reticulumresident kinase. Nature 397: 271-274.

Harding HP, Zhang Y, Bertolotti A, Zeng H, Ron D. 2000. Perk is essential for translational regulation and cell survival during the unfolded protein response. Mol Cell 5: 897-904.

Harding HP, Zhang Y, Zeng H, Novoa I, Lu PD, Calfon M, Sadri N, Yun C, Popko B, Paules R, et al. 2003. An integrated stress response regulates amino acid metabolism and resistance to oxidative stress. Mol Cell 11: 619-633.

Hartshorn KL, Collamer M, Auerbach M, Myers JB, Pavlotsky N, Tauber AI. 1988. Effects of influenza A virus on human neutrophil calcium metabolism. J Immunol 141: $1295-1301$.

Hasenfuss G, Pieske B. 2002. Calcium cycling in congestive heart failure. J Mol Cell Cardiol 34: 951-969.

Haughey NJ, Mattson MP. 2002. Calcium dysregulation and neuronal apoptosis by the HIV-1 proteins Tat and gp120. J Acquir Immune Defic Syndr 31 Suppl 2: S55-S61.

Heighway J, Betticher DC, Hoban PR, Altermatt HJ, Cowen R. 1996. Coamplification in tumors of KRAS2, type 2 inositol 1,4,5 triphosphate receptor gene, and a novel human gene, KRAG. Genomics 35: 207-214.

Hermanson D, Addo SN, Bajer AA, Marchant JS, Das SG, Srinivasan B, Al-Mousa F, Michelangeli F, Thomas DD, Lebien TW, et al. 2009. Dual mechanisms of sHA 14-1 in inducing cell death through endoplasmic reticulum and mitochondria. Mol Pharmacol 76: 667-678.

Hetz C, Russelakis-Carneiro M, Maundrell K, Castilla J, Soto C. 2003. Caspase-12 and endoplasmic reticulum stress mediate neurotoxicity of pathological prion protein. EMBO J 22: 5435-5445.

Hjelmqvist L, Tuson M, Marfany G, Herrero E, Balcells S, Gonzalez-Duarte R. 2002. ORMDL proteins are a conserved new family of endoplasmic reticulum membrane proteins. Genome Biol 3: RESEARCH0027. doi:101186/ gb-2002-3-6-research0027.

Hollien J, Weissman JS. 2006. Decay of endoplasmic reticulum-localized mRNAs during the unfolded protein response. Science 313: 104-107.

Hoshijima M, Ikeda Y, Iwanaga Y, Minamisawa S, Date MO, Gu Y, Iwatate M, Li M, Wang L, Wilson JM, et al. 2002. Chronic suppression of heart-failure progression by a pseudophosphorylated mutant of phospholamban via in vivo cardiac rAAV gene delivery. Nat Med 8: 864-871. 
D. Mekahli et al.

Hoyer-Hansen M, Jaattela M. 2007. Connecting endoplasmic reticulum stress to autophagy by unfolded protein response and calcium. Cell Death Differ 14: 1576-1582.

Hsu YL, Wu LY, Kuo PL. 2009. Dehydrocostuslactone, a medicinal plant-derived sesquiterpene lactone, induces apoptosis coupled to endoplasmic reticulum stress in liver cancer cells. J Pharmacol Exp Ther 329: 808-819.

Hu Y, Belke D, Suarez J, Swanson E, Clark R, Hoshijima M, Dillmann WH. 2005. Adenovirus-mediated overexpression of $O$-GlcNAcase improves contractile function in the diabetic heart. Circ Res 96: 1006-1013.

Huang TJ, Sayers NM, Fernyhough P, Verkhratsky A. 2002. Diabetes-induced alterations in calcium homeostasis in sensory neurones of streptozotocin-diabetic rats are restricted to lumbar ganglia and are prevented by neurotrophin-3. Diabetologia 45: 560-570.

Huang F, Shan J, Reiken S, Wehrens XH, Marks AR. 2006 Analysis of calstabin2 (FKBP12.6)-ryanodine receptor interactions: rescue of heart failure by calstabin2 in mice. Proc Natl Acad Sci 103: 3456-3461.

Hung JY, Hsu YL, Ni WC, Tsai YM, Yang CJ, Kuo PL, Huang MS. 2010. Oxidative and endoplasmic reticulum stress signaling are involved in dehydrocostuslactone-mediated apoptosis in human non-small cell lung cancer cells. Lung Cancer 68: 355-365.

Inesi G, Prasad AM, Pilankatta R. 2008. The $\mathrm{Ca}^{2+}$ ATPase of cardiac sarcoplasmic reticulum: Physiological role and relevance to diseases. Biochem Biophys Res Commun 369: $182-187$

Inoue $\mathrm{H}$, Tanizawa $\mathrm{Y}$, Wasson J, Behn P, Kalidas K, BernalMizrachi E, Mueckler M, Marshall H, Donis-Keller H, Crock P, et al. 1998. A gene encoding a transmembrane protein is mutated in patients with diabetes mellitus and optic atrophy (Wolfram syndrome). Nat Genet 20: $143-148$.

Irvine RF. 1990. Quantal $\mathrm{Ca}^{2+}$ release and the control of $\mathrm{Ca}^{2+}$ entry by inositol phosphates-a possible mechanism. FEBS Lett 263: 5-9.

Jakobsen CH, Storvold GL, Bremseth H, Follestad T, Sand K, Mack M, Olsen KS, Lundemo AG, Iversen JG, Krokan HE, et al. 2008. DHA induces ER stress and growth arrest in human colon cancer cells: associations with cholesterol and calcium homeostasis. J Lipid Res 49: 2089-2100.

Janssen K, Horn S, Niemann MT, Daniel PT, SchulzeOsthoff K, Fischer U. 2009. Inhibition of the $\mathrm{ER} \mathrm{Ca}^{2+}$ pump forces multidrug-resistant cells deficient in Bak and Bax into necrosis. J Cell Sci 122: 4481-4491.

Jaski BE, Jessup ML, Mancini DM, Cappola TP, Pauly DF, Greenberg B, Borow K, Dittrich H, Zsebo KM, Hajjar RJ. 2009. Calcium upregulation by percutaneous administration of gene therapy in cardiac disease (CUPID Trial), a first-in-human phase $1 / 2$ clinical trial. J Card Fail 15: 171-181.

Jeschke MG, Gauglitz GG, Song J, Kulp GA, Finnerty CC, Cox RA, Barral JM, Herndon DN, Boehning D. 2010. Calcium and ER stress mediate hepatic apoptosis after burn injury. J Cell Mol Med 13: 1857-1865.

Jie H, Donghua H, Xingkui X, Liang G, Wenjun W, Xiaoyan H, Zhen C. 2007. Homoharringtonine-induced apoptosis of MDS cell line MUTZ-1 cells is mediated by the endoplasmic reticulum stress pathway. Leuk Lymphoma 48: $964-977$.
Johnson AJ, Hsu AL, Lin HP, Song X, Chen CS. 2002. The cyclo-oxygenase- 2 inhibitor celecoxib perturbs intracellular calcium by inhibiting endoplasmic reticulum $\mathrm{Ca}^{2+}$. ATPases: a plausible link with its anti-tumour effect and cardiovascular risks. Biochem J 366: 831-837.

Kanekura K, Suzuki H, Aiso S, Matsuoka M. 2009. ER stress and unfolded protein response in amyotrophic lateral sclerosis. Mol Neurobiol 39: 81-89.

Kang S, Kang J, Kwon H, Frueh D, Yoo SH, Wagner G, Park S. 2008. Effects of redox potential and $\mathrm{Ca}^{2+}$ on the inositol 1,4,5-trisphosphate receptor L3-1 loop region: implications for receptor regulation. J Biol Chem 283: 25567-25575.

Karakikes I, Kim M, Hadri L, Sakata S, Sun Y, Zhang W, Chemaly ER, Hajjar RJ, Lebeche D. 2009. Gene remodeling in type 2 diabetic cardiomyopathy and its phenotypic rescue with SERCA2a. PLoS One 4: e6474. doi:101371/ journalpone 0006474 .

Kawada H, Nishiyama C, Takagi A, Tokura T, Nakano N, Maeda K, Mayuzumi N, Ikeda S, Okumura K, Ogawa H. 2005. Transcriptional regulation of ATP2C1 gene by $\mathrm{Sp} 1$ and YY1 and reduced function of its promoter in Hailey-Hailey disease keratinocytes. J Invest Dermatol 124: $1206-1214$

Kawase Y, Hajjar RJ. 2008. The cardiac sarcoplasmic/endoplasmic reticulum calcium ATPase: a potent target for cardiovascular diseases. Nat Clin Pract Cardiovasc Med 5: 554-565.

Keay S, Baldwin BR, Smith MW, Wasserman SS, Goldman WF. 1995. Increases in $\left[\mathrm{Ca}^{2+}\right]_{\mathrm{i}}$ mediated by the 92.5-kDa putative cell membrane receptor for HCMV gp86. Am J Physiol 269: C11-C21.

Kim I, Xu W, Reed JC. 2008. Cell death and endoplasmic reticulum stress: disease relevance and therapeutic opportunities. Nat Rev Drug Discov 7: 1013-1030.

Kim HW, Ch YS, Lee HR, Park SY, Kim YH. 2001. Diabetic alterations in cardiac sarcoplasmic reticulum $\mathrm{Ca}^{2+}$ ATPase and phospholamban protein expression. Life Sci 70: $367-379$.

Knobler H, Savion N, Shenkman B, Kotev-Emeth S, Varon D. 1998. Shear-induced platelet adhesion and aggregation on subendothelium are increased in diabetic patients. Thromb Res 90: 181-190.

Kobayashi T, Taguchi K, Takenouchi Y, Matsumoto T, Kamata K. 2007. Insulin-induced impairment via peroxynitrite production of endothelium-dependent relaxation and sarco/endoplasmic reticulum $\mathrm{Ca}^{2+}$-ATPase function in aortas from diabetic rats. Free Radic Biol Med 43: 431-443.

Korkotian E, Schwarz A, Pelled D, Schwarzmann G, Segal M, Futerman AH. 1999. Elevation of intracellular glucosylceramide levels results in an increase in endoplasmic reticulum density and in functional calcium stores in cultured neurons. J Biol Chem 274: 21673-21678.

Korosec B, Glavac D, Rott T, Ravnik-Glavac M. 2006. Alterations in the ATP2A2 gene in correlation with colon and lung cancer. Cancer Genet Cytogenet 171: 105-111.

Korosec B, Glavac D, Volavsek M, Ravnik-Glavac M. 2008. Alterations in genes encoding sarcoplasmic-endoplasmic reticulum $\mathrm{Ca}^{2+}$ pumps in association with head and neck squamous cell carcinoma. Cancer Genet Cytogenet 181: $112-118$. 
Kouroku Y, Fujita E, Tanida I, Ueno T, Isoai A, Kumagai H, Ogawa S, Kaufman RJ, Kominami E, Momoi T. 2007. ER stress (PERK/eIF2 $\alpha$ phosphorylation) mediates the polyglutamine-induced LC3 conversion, an essential step for autophagy formation. Cell Death Differ 14: 230-239.

Kranias EG, Bers DM. 2007. Calcium and cardiomyopathies. Subcell Biochem 45: 523-537.

Kroemer G, Galluzzi L, Brenner C. 2007. Mitochondrial membrane permeabilization in cell death. Physiol Rev 87: 99-163.

Kruglikov I, Gryshchenko O, Shutov L, Kostyuk E, Kostyuk P, Voitenko N. 2004. Diabetes-induced abnormalities in ER calcium mobilization in primary and secondary nociceptive neurons. Pflugers Arch 448: 395-401.

Kulkarni RN, Roper MG, Dahlgren G, Shih DQ, Kauri LM, Peters JL, Stoffel M, Kennedy RT. 2004. Islet secretory defect in insulin receptor substrate 1 null mice is linked with reduced calcium signaling and expression of sarco(endo)plasmic reticulum $\mathrm{Ca}^{2+}$-ATPase (SERCA)-2b and -3. Diabetes 53: 1517-1525.

Lai P, Michelangeli F. 2009. Changes in expression and activity of the secretory pathway $\mathrm{Ca}^{2+}$ ATPase 1 (SPCA1) in A7r5 vascular smooth muscle cells cultured at different glucose concentrations. Biosci Rep 29: 397-404.

Lai WW, Yang JS, Lai KC, Kuo CL, Hsu CK, Wang CK, Chang CY, Lin JJ, Tang NY, Chen PY, et al. 2009. Rhein induced apoptosis through the endoplasmic reticulum stress, caspase- and mitochondria-dependent pathways in SCC-4 human tongue squamous cancer cells. In Vivo 23: 309-316.

Lee B, Jonas JC, Weir GC, Laychock SG. 1999. Glucose regulates expression of inositol 1,4,5-trisphosphate receptor isoforms in isolated rat pancreatic islets. Endocrinology 140: $2173-2182$

Lee SY, Lee MS, Cherla RP, Tesh VL. 2008. Shiga toxin 1 induces apoptosis through the endoplasmic reticulum stress response in human monocytic cells. Cell Microbiol 10: $770-780$.

Lehnart SE, Wehrens XH, Marks AR. 2005. Defective ryanodine receptor interdomain interactions may contribute to intracellular $\mathrm{Ca}^{2+}$ leak: a novel therapeutic target in heart failure. Circulation 111: 3342-3346.

Lehnart SE, Mongillo M, Bellinger A, Lindegger N, Chen BX, Hsueh W, Reiken S, Wronska A, Drew LJ, Ward CW, et al. 2008. Leaky $\mathrm{Ca}^{2+}$ release channel/ryanodine receptor 2 causes seizures and sudden cardiac death in mice. J Clin Invest 118: 2230-2245.

Lei K, Davis RJ. 2003. JNK phosphorylation of Bim-related members of the Bcl2 family induces Bax-dependent apoptosis. Proc Natl Acad Sci 100: 2432-2437.

Leonardi O, Mints G, Hussain MA. 2003. $\beta$-cell apoptosis in the pathogenesis of human type 2 diabetes mellitus. Eur $J$ Endocrinol 149: 99-102.

Levine B, Kroemer G. 2008. Autophagy in the pathogenesis of disease. Cell 132: 27-42.

Levy J. 1999. Abnormal cell calcium homeostasis in type 2 diabetes mellitus: a new look on old disease. Endocrine 10: $1-6$.

Li Y, Ge M, Ciani L, Kuriakose G, Westover EJ, Dura M, Covey DF, Freed JH, Maxfield FR, Lytton J, et al. 2004.
Diseases with a Low ER Calcium Concentration

Enrichment of endoplasmic reticulum with cholesterol inhibits sarcoplasmic-endoplasmic reticulum calcium ATPase-2b activity in parallel with increased order of membrane lipids: implications for depletion of endoplasmic reticulum calcium stores and apoptosis in cholesterol-loaded macrophages. J Biol Chem 279: 37030-37039.

Li G, Mongillo M, Chin KT, Harding H, Ron D, Marks AR, Tabas I. 2009. Role of ERO1- $\alpha$-mediated stimulation of inositol 1,4,5-triphosphate receptor activity in endoplasmic reticulum stress-induced apoptosis. J Cell Biol 186: 783-792.

Liao PC, Tan SK, Lieu CH, Jung HK. 2008. Involvement of endoplasmic reticulum in paclitaxel-induced apoptosis. J Cell Biochem 104: 1509-1523.

Lievremont JP, Rizzuto R, Hendershot L, Meldolesi J. 1997. $\mathrm{BiP}$, major chaperone protein of the endoplasmic reticulum lumen, plays a direct and important role in the storage of the rapidly exchanging pool of $\mathrm{Ca}^{2+}$. J Biol Chem 272: 30873-30879.

Lin JH, Li H, Yasumura D, Cohen HR, Zhang C, Panning B, Shokat KM, Lavail MM, Walter P. 2007a. IRE1 signaling affects cell fate during the unfolded protein response. Science 318: 944-949.

Lin JH, Li H, Zhang Y, Ron D, Walter P. 2009. Divergent effects of PERK and IRE1 signaling on cell viability. PLoS One 4: e4170. doi:101371/journalpone0004170.

Lin JP, Yang JS, Chang NW, Chiu TH, Su CC, Lu KW, Ho YT, Yeh CC, Yang MD, Lin HJ, et al. 2007b. GADD153 mediates berberine-induced apoptosis in human cervical cancer Ca ski cells. Anticancer Res 27: 3379-3386.

Lindenmeyer MT, Rastaldi MP, Ikehata M, Neusser MA, Kretzler M, Cohen CD, Schlondorff D. 2008. Proteinuria and hyperglycemia induce endoplasmic reticulum stress. J Am Soc Nephrol 19: 2225-2236.

Lindholm D, Wootz H, Korhonen L. 2006. ER stress and neurodegenerative diseases. Cell Death Differ 13: 385-392.

Lipskaia L, Hulot JS, Lompre AM. 2009. Role of sarco/endoplasmic reticulum calcium content and calcium ATPase activity in the control of cell growth and proliferation. Pflugers Arch 457: 673-685.

Liu LH, Boivin GP, Prasad V, Periasamy M, Shull GE. 2001. Squamous cell tumors in mice heterozygous for a null allele of Atp2a2, encoding the sarco(endo)plasmic reticulum $\mathrm{Ca}^{2+}$-ATPase isoform $2 \mathrm{Ca}^{2+}$ pump. J Biol Chem 276: 26737-26740.

Liu G, Sun Y, Li Z, Song T, Wang H, Zhang Y, Ge Z. 2008. Apoptosis induced by endoplasmic reticulum stress involved in diabetic kidney disease. Biochem Biophys Res Commun 370: 651-656.

Lloyd-Evans E, Pelled D, Riebeling C, Bodennec J, de-Morgan A, Waller H, Schiffmann R, Futerman AH. 2003. Glucosylceramide and glucosylsphingosine modulate calcium mobilization from brain microsomes via different mechanisms. J Biol Chem 278: 23594-23599.

Lopez JJ, Jardin I, Bobe R, Pariente JA, Enouf J, Salido GM, Rosado JA. 2008. STIM1 regulates acidic $\mathrm{Ca}^{2+}$ store refilling by interaction with SERCA3 in human platelets. Biochem Pharmacol 75: 2157-2164.

Lorenzon NM, Beam KG. 2008. Disease causing mutations of calcium channels. Channels (Austin) 2: 163-179. 
D. Mekahli et al.

Lucero HA, Kaminer B. 1999. The role of calcium on the activity of ERcalcistorin/protein-disulfide isomerase and the significance of the C-terminal and its calcium binding. A comparison with mammalian proteindisulfide isomerase. J Biol Chem 274: 3243-3251.

Luciani DS, Gwiazda KS, Yang TL, Kalynyak TB, Bychkivska Y, Frey MH, Jeffrey KD, Sampaio AV, Underhill TM, Johnson JD. 2009. Roles of $\mathrm{IP}_{3} \mathrm{R}$ and $\mathrm{RyR} \mathrm{Ca}{ }^{2+}$ channels in endoplasmic reticulum stress and $\beta$-cell death. Diabetes 58: $422-432$.

Ma Y, Hendershot LM. 2004. ER chaperone functions during normal and stress conditions. J Chem Neuroanat 28: $51-65$.

Ma L, Zhu B, Chen X, Liu J, Guan Y, Ren J. 2008. Abnormalities of sarcoplasmic reticulum $\mathrm{Ca}^{2+}$ mobilization in aortic smooth muscle cells from streptozotocin-induced diabetic rats. Clin Exp Pharmacol Physiol 35: 568-573.

Magyar JE, Gamberucci A, Konta L, Margittai E, Mandl J, Banhegyi G, Benedetti A, Csala M. 2009. Endoplasmic reticulum stress underlying the pro-apoptotic effect of epigallocatechin gallate in mouse hepatoma cells. Int $J$ Biochem Cell Biol 41: 694-700.

Mahabusarakam W, Iriyachitra P, Taylor WC. 1987. Chemical constituents of garcinia mangostana. J Nat Prod 50: $474-478$.

Mahn K, Hirst SJ, Ying S, Holt MR, Lavender P, Ojo OO, Siew L, Simcock DE, McVicker CG, Kanabar V, et al. 2009. Diminished sarco/endoplasmic reticulum $\mathrm{Ca}^{2+}$ ATPase (SERCA) expression contributes to airway remodelling in bronchial asthma. Proc Natl Acad Sci 106: $10775-10780$.

Malhotra JD, Kaufman RJ. 2007. The endoplasmic reticulum and the unfolded protein response. Semin Cell Dev Biol 18: 716-731.

Manninen A, Saksela K. 2002. HIV-1 Nef interacts with inositol trisphosphate receptor to activate calcium signaling in T cells. J Exp Med 195: 1023-1032.

Marciniak SJ, Yun CY, Oyadomari S, Novoa I, Zhang Y, Jungreis R, Nagata K, Harding HP, Ron D. 2004. CHOP induces death by promoting protein synthesis and oxidation in the stressed endoplasmic reticulum. Genes Dev 18: 3066-3077.

Marx SO, Reiken S, Hisamatsu Y, Jayaraman T, Burkhoff D, Rosemblit N, Marks AR. 2000. PKA phosphorylation dissociates FKBP12.6 from the calcium release channel (ryanodine receptor): defective regulation in failing hearts. Cell 101: 365-376.

Mattson MP. 2007. Calcium and neurodegeneration. Aging Cell 6: $337-350$.

Mayne M, Holden CP, Nath A, Geiger JD. 2000. Release of calcium from inositol 1,4,5-trisphosphate receptorregulated stores by HIV-1 Tat regulates TNF- $\alpha$ production in human macrophages. JImmunol 164: 6538-6542.

McCullough KD, Martindale JL, Klotz LO, Aw TY, Holbrook NJ. 2001. Gadd153 sensitizes cells to endoplasmic reticulum stress by down-regulating $\mathrm{Bcl} 2$ and perturbing the cellular redox state. Mol Cell Biol 21: 1249-1259.

Michalak M, Robert Parker JM, Opas M. 2002. $\mathrm{Ca}^{2+}$ signaling and calcium binding chaperones of the endoplasmic reticulum. Cell Calcium 32: 269-278.
Mikoshiba K. 2007. $\mathrm{IP}_{3}$ receptor $/ \mathrm{Ca}^{2+}$ channel: from discovery to new signaling concepts. J Neurochem 102: 1426-1446.

Missiaen L, De Smedt H, Droogmans G, Casteels R. 1992. $\mathrm{Ca}^{2+}$ release induced by inositol 1,4,5-trisphosphate is a steady-state phenomenon controlled by luminal $\mathrm{Ca}^{2+}$ in permeabilized cells. Nature 357: 599-602.

Missiaen L, Robberecht W, Van Den Bosch L, Callewaert G, Parys JB, Wuytack F, Raeymaekers L, Nilius B, Eggermont J, De Smedt H. 2000. Abnormal intracellular $\mathrm{Ca}^{2+}$ homeostasis and disease. Cell Calcium 28: 1-21.

Moffatt MF, Kabesch M, Liang L, Dixon AL, Strachan D, Heath S, Depner M, von Berg A, Bufe A, Rietschel E, et al. 2007. Genetic variants regulating ORMDL3 expression contribute to the risk of childhood asthma. Nature 448: $470-473$.

Moller JT, Cluitmans P, Rasmussen LS, Houx P, Rasmussen $\mathrm{H}$, Canet J, Rabbitt P, Jolles J, Larsen K, Hanning CD, et al. 1998. Long-term postoperative cognitive dysfunction in the elderly ISPOCD1 study. ISPOCD investigators. International Study of Post-Operative Cognitive Dysfunction. Lancet 351: 857-861.

Moncada S, Erusalimsky JD. 2002. Does nitric oxide modulate mitochondrial energy generation and apoptosis? Nat Rev Mol Cell Biol 3: 214-220.

Monteith GR, McAndrew D, Faddy HM, Roberts-Thomson SJ. 2007. Calcium and cancer: targeting $\mathrm{Ca}^{2+}$ transport. Nat Rev Cancer 7: 519-530.

Nagata E, Tanaka K, Gomi S, Mihara B, Shirai T, Nogawa S, Nozaki H, Mikoshiba K, Fukuuchi Y. 1994. Alteration of inositol 1,4,5-trisphosphate receptor after six-hour hemispheric ischemia in the gerbil brain. Neuroscience 61: 983-990.

Nakano K, Isegawa Y, Zou P, Tadagaki K, Inagi R, Yamanishi K. 2003. Kaposi's sarcoma-associated herpesvirus (KSHV)-encoded vMIP-I and vMIP-II induce signal transduction and chemotaxis in monocytic cells. Arch Virol 148: 871-890.

Nakano T, Watanabe H, Ozeki M, Asai M, Katoh H, Satoh H, Hayashi H. 2006. Endoplasmic reticulum $\mathrm{Ca}^{2+}$ depletion induces endothelial cell apoptosis independently of caspase-12. Cardiovasc Res 69: 908-915.

Nawrocki ST, Carew JS, Pino MS, Highshaw RA, Dunner K Jr, Huang P, Abbruzzese JL, McConkey DJ. 2005. Bortezomib sensitizes pancreatic cancer cells to endoplasmic reticulum stress-mediated apoptosis. Cancer Res 65: $11658-11666$.

Nelson TE, Nelson KE. 1990. Intra- and extraluminal sarcoplasmic reticulum membrane regulatory sites for $\mathrm{Ca}^{2+}$ induced $\mathrm{Ca}^{2+}$ release. FEBS Lett 263: 292-294.

Nicolau J, De Souza DN, Simoes A. 2009. Alteration of $\mathrm{Ca}^{2+}$-ATPase activity in the homogenate, plasma membrane and microsomes of the salivary glands of streptozotocin-induced diabetic rats. Cell Biochem Funct 27: $128-134$.

Nieto-Miguel T, Fonteriz RI, Vay L, Gajate C, LopezHernandez S, Mollinedo F. 2007. Endoplasmic reticulum stress in the proapoptotic action of edelfosine in solid tumor cells. Cancer Res 67: 10368-10378.

Norman JP, Perry SW, Reynolds HM, Kiebala M, De Mesy Bentley KL, Trejo M, Volsky DJ, Maggirwar SB, Dewhurst S, Masliah E, et al. 2008. HIV-1 Tat activates neuronal 
ryanodine receptors with rapid induction of the unfolded protein response and mitochondrial hyperpolarization. PLoS One 3: e3731. doi:101371/journalpone0003731.

Oakes SA, Scorrano L, Opferman JT, Bassik MC, Nishino M, Pozzan T, Korsmeyer SJ. 2005. Proapoptotic BAX and BAK regulate the type 1 inositol trisphosphate receptor and calcium leak from the endoplasmic reticulum. Proc Natl Acad Sci 102: 105-110.

Odermatt A, Taschner PE, Khanna VK, Busch HF, Karpati G, Jablecki CK, Breuning MH, MacLennan DH. 1996 Mutations in the gene-encoding SERCA1, the fast-twitch skeletal muscle sarcoplasmic reticulum $\mathrm{Ca}^{2+}$ ATPase, are associated with Brody disease. Nat Genet 14: 191-194.

Ogata M, Hino S, Saito A, Morikawa K, Kondo S, Kanemoto S, Murakami T, Taniguchi M, Tanii I, Yoshinaga K, et al. 2006. Autophagy is activated for cell survival after endoplasmic reticulum stress. Mol Cell Biol 26: 9220-9231.

O’Neil BJ, McKeown TR, DeGracia DJ, Alousi SS, Rafols JA, White BC. 1999. Cell death, calcium mobilization, and immunostaining for phosphorylated eukaryotic initiation factor $2-\alpha$ (eIF $2 \alpha)$ in neuronally differentiated NB-104 cells: arachidonate and radical-mediated injury mechanisms. Resuscitation 41: 71-83.

Ong DS, Mu TW, Palmer AE, Kelly JW. 2010. Endoplasmic reticulum $\mathrm{Ca}^{2+}$ increases enhance mutant glucocerebrosidase proteostasis. Nat Chem Biol 6: 424-432.

Onozuka T, Sawamura D, Goto M, Yokota K, Shimizu H. 2006. Possible role of endoplasmic reticulum stress in the pathogenesis of Darier's disease. J Dermatol Sci 41: 217-220.

O’Rourke B, Kass DA, Tomaselli GF, Kaab S, Tunin R, Marban E. 1999. Mechanisms of altered excitationcontraction coupling in canine tachycardia-induced heart failure, I: experimental studies. Circ Res 84: $562-$ 570.

Osman AA, Saito M, Makepeace C, Permutt MA, Schlesinger P, Mueckler M. 2003. Wolframin expression induces novel ion channel activity in endoplasmic reticulum membranes and increases intracellular calcium. J Biol Chem 278: 52755-52762.

Oyadomari S, Mori M. 2004. Roles of CHOP/GADD153 in endoplasmic reticulum stress. Cell Death Differ 11: 381-389.

Oyadomari S, Takeda K, Takiguchi M, Gotoh T, Matsumoto M, Wada I, Akira S, Araki E, Mori M. 2001. Nitric oxide-induced apoptosis in pancreatic $\beta$ cells is mediated by the endoplasmic reticulum stress pathway. Proc Natl Acad Sci 98: 10845-10850.

Ozcan U, Cao Q, Yilmaz E, Lee AH, Iwakoshi NN, Ozdelen E, Tuncman G, Gorgun C, Glimcher LH, Hotamisligil GS. 2004. Endoplasmic reticulum stress links obesity, insulin action, and type 2 diabetes. Science 306: 457-461.

Pacifico F, Ulianich L, De Micheli S, Treglia S, Leonardi A, Vito P, Formisano S, Consiglio E, Di Jeso B. 2003. The expression of the sarco/endoplasmic reticulum $\mathrm{Ca}^{2+}$ ATPases in thyroid and its down-regulation following neoplastic transformation. J Mol Endocrinol 30: 399-409.

Papp S, Dziak E, Michalak M, Opas M. 2003. Is all of the endoplasmic reticulum created equal? The effects of the heterogeneous distribution of endoplasmic reticulum $\mathrm{Ca}^{2+}$-handling proteins. J Cell Biol 160: 475-479.
Park KS, Poburko D, Wollheim CB, Demaurex N. 2009. Amiloride derivatives induce apoptosis by depleting ER $\mathrm{Ca}^{2+}$ stores in vascular endothelial cells. Br J Pharmacol 156: $1296-1304$.

Parsons JT, Churn SB, DeLorenzo RJ. 1999. Global ischemia-induced inhibition of the coupling ratio of calcium uptake and ATP hydrolysis by rat whole brain microsomal $\mathrm{Mg}^{2+} / \mathrm{Ca}^{2+}$ ATPase. Brain Res 834: 32-41.

Paschen W, Mengesdorf T. 2005. Endoplasmic reticulum stress response and neurodegeneration. Cell Calcium 38: 409-415.

Pattacini L, Mancini M, Mazzacurati L, Brusa G, Benvenuti M, Martinelli G, Baccarani M, Santucci MA. 2004. Endoplasmic reticulum stress initiates apoptotic death induced by STI571 inhibition of p210 bcr-abl tyrosine kinase. Leuk Res 28: 191-202.

Pattni K, Millard TH, Banting G. 2003. Calpain cleavage of the $\mathrm{B}$ isoform of $\operatorname{Ins}(1,4,5) \mathrm{P}_{3}$ 3-kinase separates the catalytic domain from the membrane anchoring domain. Biochem J 375: 643-651.

Pelled D, Lloyd-Evans E, Riebeling C, Jeyakumar M, Platt FM, Futerman AH. 2003. Inhibition of calcium uptake via the sarco/endoplasmic reticulum $\mathrm{Ca}^{2+}$-ATPase in a mouse model of Sandhoff disease and prevention by treatment with N-butyldeoxynojirimycin. J Biol Chem 278: $29496-29501$.

Pelled D, Trajkovic-Bodennec S, Lloyd-Evans E, Sidransky E, Schiffmann R, Futerman AH. 2005. Enhanced calcium release in the acute neuronopathic form of Gaucher disease. Neurobiol Dis 18: 83-88.

Pereira L, Matthes J, Schuster I, Valdivia HH, Herzig S, Richard S, Gomez AM. 2006. Mechanisms of $\left[\mathrm{Ca}^{2+}\right]_{i}$ transient decrease in cardiomyopathy of $\mathrm{db} / \mathrm{db}$ type 2 diabetic mice. Diabetes 55: 608-615.

Petersen OH, Tepikin A, Park MK. 2001. The endoplasmic reticulum: one continuous or several separate $\mathrm{Ca}^{2+}$ stores? Trends Neurosci 24: 271-276.

Pirot P, Cardozo AK, Eizirik DL. 2008. Mediators and mechanisms of pancreatic $\beta$-cell death in type 1 diabetes. Arq Bras Endocrinol Metabol 52: 156-165.

Pozzan T, Rizzuto R, Volpe P, Meldolesi J. 1994. Molecular and cellular physiology of intracellular calcium stores. Physiol Rev 74: 595-636.

Prusiner SB. 1998. Prions. Proc Natl Acad Sci 95: $13363-$ 13383.

Putcha GV, Le S, Frank S, Besirli CG, Clark K, Chu B, Alix S, Youle RJ, LaMarche A, Maroney AC, et al. 2003. JNK-mediated BIM phosphorylation potentiates BAXdependent apoptosis. Neuron 38: 899-914.

Puthalakath H, O'Reilly LA, Gunn P, Lee L, Kelly PN, Huntington ND, Hughes PD, Michalak EM, McKimmBreschkin J, Motoyama N, et al. 2007. ER stress triggers apoptosis by activating BH3-only protein Bim. Cell 129: 1337-1349.

Putney JW Jr. 1986. A model for receptor-regulated calcium entry. Cell Calcium 7: 1-12.

Pyrko P, Kardosh A, Liu YT, Soriano N, Xiong W, Chow RH, Uddin J, Petasis NA, Mircheff AK, Farley RA, et al. 2007. Calcium-activated endoplasmic reticulum stress as a major component of tumor cell death induced by 
D. Mekahli et al.

2,5-dimethyl-celecoxib, a non-coxib analogue of celecoxib. Mol Cancer Ther 6: 1262-1275.

Qi MY, Liu HR, Dai DZ, Li N, Dai Y. 2008. Total triterpene acids, active ingredients from Fructus Corni, attenuate diabetic cardiomyopathy by normalizing ET pathway and expression of FKBP12.6 and SERCA2a in streptozotocin-rats. J Pharm Pharmacol 60: 1687-1694.

Rahmani M, Davis EM, Crabtree TR, Habibi JR, Nguyen TK, Dent P, Grant S. 2007. The kinase inhibitor sorafenib induces cell death through a process involving induction of endoplasmic reticulum stress. Mol Cell Biol 27: 5499-5513.

Randriamboavonjy V, Pistrosch F, Bolck B, Schwinger RH, Dixit M, Badenhoop K, Cohen RA, Busse R, Fleming I. 2008. Platelet sarcoplasmic endoplasmic reticulum $\mathrm{Ca}^{2+}$. ATPase and mu-calpain activity are altered in type 2 diabetes mellitus and restored by rosiglitazone. Circulation 117: $52-60$.

Rao RV, Bredesen DE. 2004. Misfolded proteins, endoplasmic reticulum stress and neurodegeneration. Curr Opin Cell Biol 16: 653-662.

Rardon DP, Cefali DC, Mitchell RD, Seiler SM, Hathaway DR, Jones LR. 1990. Digestion of cardiac and skeletal muscle junctional sarcoplasmic reticulum vesicles with calpain II. Effects on the $\mathrm{Ca}^{2+}$ release channel. Circ Res 67: $84-96$.

Reiken S, Gaburjakova M, Gaburjakova J, He KL, Prieto A, Becker E, Yi GH, Wang J, Burkhoff D, Marks AR. 2001. $ß$-adrenergic receptor blockers restore cardiac calcium release channel (ryanodine receptor) structure and function in heart failure. Circulation 104: 2843-2848.

Reiken S, Lacampagne A, Zhou H, Kherani A, Lehnart SE Ward C, Huang F, Gaburjakova M, Gaburjakova J, Rosemblit N, et al. 2003. PKA phosphorylation activates the calcium release channel (ryanodine receptor) in skeletal muscle: defective regulation in heart failure. $J$ Cell Biol 160: 919-928.

Ren J, Gintant GA, Miller RE, Davidoff AJ. 1997. High extracellular glucose impairs cardiac E-C coupling in a glycosylation-dependent manner. Am J Physiol 273: $\mathrm{H} 2876-\mathrm{H} 2883$.

Rengifo J, Gibson CJ, Winkler E, Collin T, Ehrlich BE. 2007. Regulation of the inositol 1,4,5-trisphosphate receptor type I by O-GlcNAc glycosylation. J Neurosci 27: 13813-13821.

Reuter H, Gronke S, Adam C, Ribati M, Brabender J, Zobel C, Frank KF, Wippermann J, Schwinger RH, Brixius K, et al. 2008. Sarcoplasmic $\mathrm{Ca}^{2+}$ release is prolonged in nonfailing myocardium of diabetic patients. Mol Cell Biochem 308: 141-149.

Rigaud M, Gemes G, Weyker PD, Cruikshank JM, Kawano T, Wu HE, Hogan QH. 2009. Axotomy depletes intracellular calcium stores in primary sensory neurons. Anesthesiology 111: 381-392.

Rizzuto R, Marchi S, Bonora M, Aguiari P, Bononi A, De Stefani D, Giorgi C, Leo S, Rimessi A, Siviero R, et al. 2009. $\mathrm{Ca}^{2+}$ transfer from the ER to mitochondria: when, how and why. Biochim Biophys Acta 1787: $1342-1351$.

Roach JC, Deutsch K, Li S, Siegel AF, Bekris LM, Einhaus DC, Sheridan CM, Glusman G, Hood L, Lernmark A, et al. 2006. Genetic mapping at 3-kilobase resolution reveals inositol 1,4,5-triphosphate receptor 3 as a risk factor for type 1 diabetes in Sweden. Am J Hum Genet 79: $614-627$.

Robinson LC, Marchant JS. 2008. Enhanced $\mathrm{Ca}^{2+}$ leak from $\mathrm{ER} \mathrm{Ca}^{2+}$ stores induced by hepatitis C NS5A protein. Biochem Biophys Res Commun 368: 593-599.

Roe MW, Philipson LH, Frangakis CJ, Kuznetsov A, Mertz RJ, Lancaster ME, Spencer B, Worley JF III, Dukes ID. 1994. Defective glucose-dependent endoplasmic reticulum $\mathrm{Ca}^{2+}$ sequestration in diabetic mouse islets of Langerhans. J Biol Chem 269: 18279-18282.

Ron D, Walter P. 2007. Signal integration in the endoplasmic reticulum unfolded protein response. Nat Rev Mol Cell Biol 8: 519-529.

Rong Y, Distelhorst CW. 2008. Bcl-2 protein family members: versatile regulators of calcium signaling in cell survival and apoptosis. Annu Rev Physiol 70: 73-91.

Rubler S, Dlugash J, Yuceoglu YZ, Kumral T, Branwood AW, Grishman A. 1972. New type of cardiomyopathy associated with diabetic glomerulosclerosis. Am J Cardiol 30: 595-602.

Ryu EJ, Harding HP, Angelastro JM, Vitolo OV, Ron D, Greene LA. 2002. Endoplasmic reticulum stress and the unfolded protein response in cellular models of Parkinson's disease. J Neurosci 22: 10690-10698.

Saavedra FR, Redondo PC, Hernandez-Cruz JM, Salido GM, Pariente JA, Rosado JA. 2004. Store-operated $\mathrm{Ca}^{2+}$ entry and tyrosine kinase pp $60^{\text {src }}$ hyperactivity are modulated by hyperglycemia in platelets from patients with non insulin-dependent diabetes mellitus. Arch Biochem Biophys 432: 261-268.

Sacchetto R, Testoni S, Gentile A, Damiani E, Rossi M, Liguori R, Drogemuller C, Mascarello F. 2009. A defective SERCA1 protein is responsible for congenital pseudomyotonia in Chianina cattle. Am J Pathol 174: 565-573.

Sakakura C, Hagiwara A, Fukuda K, Shimomura K, Takagi T, Kin S, Nakase Y, Fujiyama J, Mikoshiba K, Okazaki Y, et al. 2003. Possible involvement of inositol 1,4,5trisphosphate receptor type $3\left(\mathrm{IP}_{3} \mathrm{R} 3\right)$ in the peritoneal dissemination of gastric cancers. Anticancer Res 23: 3691-3697.

Sakata S, Lebeche D, Sakata Y, Sakata N, Chemaly ER, Liang L, Nakajima-Takenaka C, Tsuji T, Konishi N, del Monte F, et al. 2007. Transcoronary gene transfer of SERCA2a increases coronary blood flow and decreases cardiomyocyte size in a type 2 diabetic rat model. Am J Physiol 292: H1204-H1207.

Sakuntabhai A, Ruiz-Perez V, Carter S, Jacobsen N, Burge S, Monk S, Smith M, Munro CS, O'Donovan M, Craddock $\mathrm{N}$, et al. 1999. Mutations in ATP2A2, encoding a $\mathrm{Ca}^{2+}$ pump, cause Darier disease. Nat Genet 21: 271-277.

Sambrook JF. 1990. The involvement of calcium in transport of secretory proteins from the endoplasmic reticulum. Cell 61: 197-199.

Sammels E, Parys JB, Missiaen L, De Smedt H, Bultynck G. 2010. Intracellular $\mathrm{Ca}^{2+}$ storage in health and disease: a dynamic equilibrium. Cell Calcium 47: 297-314.

Sano R, Annunziata I, Patterson A, Moshiach S, Gomero E, Opferman J, Forte M, d'Azzo A. 2009. $\mathrm{G}_{\mathrm{M} 1}$-ganglioside accumulation at the mitochondria-associated ER membranes links ER stress to $\mathrm{Ca}^{2+}$-dependent mitochondrial apoptosis. Mol Cell 36: 500-511. 
Sathish V, Thompson MA, Bailey JP, Pabelick CM, Prakash YS, Sieck GC. 2009. Effect of proinflammatory cytokines on regulation of sarcoplasmic reticulum $\mathrm{Ca}^{2+}$ reuptake in human airway smooth muscle. Am J Physiol 297: L26-L34.

Sato A, Fujiwara H, Oku H, Ishiguro K, Ohizumi Y. 2004. $\alpha$-mangostin induces $\mathrm{Ca}^{2+}$-ATPase-dependent apoptosis via mitochondrial pathway in PC12 cells. J Pharmacol Sci 95: 33-40.

Savino JA III, Evans JF, Rabinowitz D, Auborn KJ, Carter TH. 2006. Multiple, disparate roles for calcium signaling in apoptosis of human prostate and cervical cancer cells exposed to diindolylmethane. Mol Cancer Ther 5: $556-563$.

Schindl R, Muik M, Fahrner M, Derler I, Fritsch R, Bergsmann J, Romanin C. 2009. Recent progress on STIM1 domains controlling Orai activation. Cell Calcium 46: 227-232.

Schmidt AG, Haghighi K, Frank B, Pater L, Dorn GW, Walsh RA, Kranias EG. 2003a. Polymorphic SERCA2a variants do not account for inter-individual differences in phospholamban-SERCA2a interactions in human heart failure. J Mol Cell Cardiol 35: 867-870.

Schmidt T, Zaib F, Samson SE, Kwan CY, Grover AK. 2003b. Peroxynitrite resistance of sarco/endoplasmic reticulum $\mathrm{Ca}^{2+}$ pump in pig coronary artery endothelium and smooth muscle. Cell Calcium 36: 77-82.

Schmitt JP, Kamisago M, Asahi M, Li GH, Ahmad F, Mende U, Kranias EG, MacLennan DH, Seidman JG, Seidman CE. 2003. Dilated cardiomyopathy and heart failure caused by a mutation in phospholamban. Science 299: 1410-1413.

Schroder M, Kaufman RJ. 2005. The mammalian unfolded protein response. Annu Rev Biochem 74: 739-789.

Scorrano L, Oakes SA, Opferman JT, Cheng EH, Sorcinelli MD, Pozzan T, Korsmeyer SJ. 2003. BAX and BAK regulation of endoplasmic reticulum $\mathrm{Ca}^{2+}:$ a control point for apoptosis. Science 300: 135-139.

Searls YM, Loganathan R, Smirnova IV, Stehno-Bittel L. 2010. Intracellular $\mathrm{Ca}^{2+}$ regulating proteins in vascular smooth muscle cells are altered with type 1 diabetes due to the direct effects of hyperglycemia. Cardiovasc Diabetol 9: 8. 2010. doi: 101186/1475-2840-9-8.

Seidler T, Hasenfuss G, Maier LS. 2007. Targeting altered calcium physiology in the heart: translational approaches to excitation, contraction, and transcription. Physiology 22: 328-334.

Seo NS, Zeng CQ, Hyser JM, Utama B, Crawford SE, Kim KJ, Hook M, Estes MK. 2008. Inaugural article: integrins $\alpha 1 \beta 1$ and $\alpha 2 \beta 1$ are receptors for the rotavirus enterotoxin. Proc Natl Acad Sci 105: 8811-8818.

Shah RD, Gonzales F, Golez E, Augustin D, Caudillo S, Abbott A, Morello J, McDonough PM, Paolini PJ, Shubeita HE. 2005. The antidiabetic agent rosiglitazone upregulates SERCA2 and enhances TNF- $\alpha$ - and LPSinduced NF-kB-dependent transcription and TNF- $\alpha$ induced IL-6 secretion in ventricular myocytes. Cell Physiol Biochem 15: 41-50.

Shao CH, Rozanski GJ, Patel KP, Bidasee KR. 2007. Dyssynchronous (non-uniform) $\mathrm{Ca}^{2+}$ release in myocytes from streptozotocin-induced diabetic rats. J Mol Cell Cardiol 42: $234-246$.
Shao CH, Wehrens XH, Wyatt TA, Parbhu S, Rozanski GJ, Patel KP, Bidasee KR. 2009. Exercise training during diabetes attenuates cardiac ryanodine receptor dysregulation. J Appl Physiol 106: 1280-1292.

Sharma K, Wang L, Zhu Y, DeGuzman A, Cao GY, Lynn RB, Joseph SK. 1999. Renal type I inositol 1,4,5-trisphosphate receptor is reduced in streptozotocin-induced diabetic rats and mice. Am J Physiol 276: F54-F61.

Sharon-Friling R, Goodhouse J, Colberg-Poley AM, Shenk T. 2006. Human cytomegalovirus pUL37x1 induces the release of endoplasmic reticulum calcium stores. Proc Natl Acad Sci 103: 19117-19122.

Shen J, Yu WM, Brotto M, Scherman JA, Guo C, Stoddard C, Nosek TM, Valdivia HH, Qu CK. 2009. Deficiency of MIP/MTMR14 phosphatase induces a muscle disorder by disrupting $\mathrm{Ca}^{2+}$ homeostasis. Nat Cell Biol 11: 769-776.

Stathopulos PB, Zheng L, Li GY, Plevin MJ, Ikura M. 2008. Structural and mechanistic insights into STIM1mediated initiation of store-operated calcium entry. Cell 135: 110-122.

Stockwin LH, Han B, Yu SX, Hollingshead MG, ElSohly MA, Gul W, Slade D, Galal AM, Newton DL. 2009 Artemisinin dimer anticancer activity correlates with heme-catalyzed reactive oxygen species generation and endoplasmic reticulum stress induction. Int $J$ Cancer 125: $1266-1275$.

Stolen TO, Hoydal MA, Kemi OJ, Catalucci D, Ceci M, Aasum E, Larsen T, Rolim N, Condorelli G, Smith GL, et al. 2009. Interval training normalizes cardiomyocyte function, diastolic $\mathrm{Ca}^{2+}$ control, and SR $\mathrm{Ca}^{2+}$ release synchronicity in a mouse model of diabetic cardiomyopathy. Circ Res 105: 527-536.

Strom TM, Hortnagel K, Hofmann S, Gekeler F, Scharfe C, Rabl W, Gerbitz KD, Meitinger T. 1998. Diabetes insipidus, diabetes mellitus, optic atrophy and deafness (DIDMOAD) caused by mutations in a novel gene (wolframin) coding for a predicted transmembrane protein. Hum Mol Genet 7: 2021-2028.

Suarez J, Scott B, Dillmann WH. 2008. Conditional increase in SERCA2a protein is able to reverse contractile dysfunction and abnormal calcium flux in established diabetic cardiomyopathy. Am J Physiol 295: R1439-R1445.

Sulaiman M, Matta MJ, Sunderesan NR, Gupta MP, Periasamy M, Gupta M. 2010. Resveratrol, an activator of SIRT1, upregulates sarcoplasmic calcium ATPase and improves cardiac function in diabetic cardiomyopathy. Am J Physiol 298: H833-H843.

Supnet C, Bezprozvanny I. 2010. The dysregulation of intracellular calcium in Alzheimer disease. Cell Calcium 47: 183-189.

Szegezdi E, Fitzgerald U, Samali A. 2003. Caspase-12 and ER-stress-mediated apoptosis: the story so far. Ann N Y Acad Sci 1010: 186-194.

Taiyab A, Sreedhar AS, Rao ChM. 2009. Hsp90 inhibitors, GA and 17AAG, lead to ER stress-induced apoptosis in rat histiocytoma. Biochem Pharmacol 78: 142-152.

Takei D, Ishihara H, Yamaguchi S, Yamada T, Tamura A, Katagiri H, Maruyama Y, Oka Y. 2006. WFS1 protein modulates the free $\mathrm{Ca}^{2+}$ concentration in the endoplasmic reticulum. FEBS Lett 580: 5635-5640. 
D. Mekahli et al.

Takenaka H, Adler PN, Katz AM. 1982. Calcium fluxes across the membrane of sarcoplasmic reticulum vesicles. J Biol Chem 257: 12649-12656.

Teshima Y, Takahashi N, Saikawa T, Hara M, Yasunaga S, Hidaka S, Sakata T. 2000. Diminished expression of sarcoplasmic reticulum $\mathrm{Ca}^{2+}$-ATPase and ryanodine sensitive $\mathrm{Ca}^{2+}$ channel mRNA in streptozotocin-induced diabetic rat heart. J Mol Cell Cardiol 32: 655-664.

Tessitore A, del P Martin M, Sano R, Ma Y, Mann L, Ingrassia A, Laywell ED, Steindler DA, Hendershot LM, d'Azzo A. 2004. $\mathrm{G}_{\mathrm{M} 1}$-ganglioside-mediated activation of the unfolded protein response causes neuronal death in a neurodegenerative gangliosidosis. Mol Cell 15: 753-766.

Thompson S, Chen X, Hui L, Toschi A, Foster DA, Drain CM. 2008. Low concentrations of a non-hydrolysable tetra-S-glycosylated porphyrin and low light induces apoptosis in human breast cancer cells via stress of the endoplasmic reticulum. Photochem Photobiol Sci 7: $1415-1421$.

Tian P, Estes MK, Hu Y, Ball JM, Zeng CQ, Schilling WP. 1995. The rotavirus nonstructural glycoprotein NSP4 mobilizes $\mathrm{Ca}^{2+}$ from the endoplasmic reticulum. J Virol 69: $5763-5772$.

Tong X, Evangelista A, Cohen RA. 2009. Targeting the redox regulation of SERCA in vascular physiology and disease. Curr Opin Pharmacol 10: 1-6.

Tong X, Ying J, Pimentel DR, Trucillo M, Adachi T, Cohen RA. 2008. High glucose oxidizes SERCA cysteine-674 and prevents inhibition by nitric oxide of smooth muscle cell migration. J Mol Cell Cardiol 44: 361-369.

Tonnesen MF, Grunnet LG, Friberg J, Cardozo AK, Billestrup N, Eizirik DL, Storling J, Mandrup-Poulsen T. 2009. Inhibition of Nuclear Factor-kB or Bax prevents endoplasmic reticulum stress- but not nitric oxidemediated apoptosis in INS-1E cells. Endocrinology 150: 4094-4103.

Tosch V, Rohde HM, Tronchere H, Zanoteli E, Monroy N, Kretz C, Dondaine N, Payrastre B, Mandel JL, Laporte J. 2006. A novel PtdIns3P and PtdIns $(3,5) \mathrm{P}_{2}$ phosphatase with an inactivating variant in centronuclear myopathy. Hum Mol Genet 15: 3098-3106.

Trost SU, Belke DD, Bluhm WF, Meyer M, Swanson E, Dillmann WH. 2002. Overexpression of the sarcoplasmic reticulum $\mathrm{Ca}^{2+}$-ATPase improves myocardial contractility in diabetic cardiomyopathy. Diabetes 51: 1166-1171.

Tsuchiya S, Tsuji M, Morio Y, Oguchi K. 2006. Involvement of endoplasmic reticulum in glycochenodeoxycholic acid-induced apoptosis in rat hepatocytes. Toxicol Lett 166: $140-149$.

Tu H, Nelson O, Bezprozvanny A, Wang Z, Lee SF, Hao YH, Serneels L, De Strooper B, Yu G, Bezprozvanny I. 2006 Presenilins form ER $\mathrm{Ca}^{2+}$ leak channels, a function disrupted by familial Alzheimer's disease-linked mutations. Cell 126: 981-993.

Van Baelen K, Dode L, Vanoevelen J, Callewaert G, De Smedt H, Missiaen L, Parys JB, Raeymaekers L, Wuytack F. 2004. The $\mathrm{Ca}^{2+} / \mathrm{Mn}^{2+}$ pumps in the Golgi apparatus. Biochim Biophys Acta 1742: 103-112.

Vanderheyden V, Devogelaere B, Missiaen L, De Smedt H, Bultynck G, Parys JB. 2009. Regulation of inositol 1,4,5-trisphosphate-induced $\mathrm{Ca}^{2+}$ release by reversible phosphorylation and dephosphorylation. Biochim Biophys Acta 1793: 959-970.

van der Kallen CJ, van Greevenbroek MM, Stehouwer CD, Schalkwijk CG. 2009. Endoplasmic reticulum stressinduced apoptosis in the development of diabetes: is there a role for adipose tissue and liver? Apoptosis 14: 1424-1434.

Vangheluwe P, Sepulveda MR, Missiaen L, Raeymaekers L, Wuytack F, Vanoevelen J. 2009. Intracellular $\mathrm{Ca}^{2+}$ and $\mathrm{Mn}^{2+}$-transport ATPases. Chem Rev 109: 47334759 .

van Kuppeveld FJ, de Jong AS, Melchers WJ, Willems PH. 2005. Enterovirus protein $2 \mathrm{~B}$ po(u)res out the calcium: a viral strategy to survive? Trends Microbiol 13: 41-44.

Vanoverberghe K, Vanden Abeele F, Mariot P, Lepage G, Roudbaraki M, Bonnal JL, Mauroy B, Shuba Y, Skryma R, Prevarskaya N. 2004. $\mathrm{Ca}^{2+}$ homeostasis and apoptotic resistance of neuroendocrine-differentiated prostate cancer cells. Cell Death Differ 11: 321-330.

Varadi A, Lebel L, Hashim Y, Mehta Z, Ashcroft SJ, Turner R. 1999. Sequence variants of the sarco(endo)plasmic reticulum $\mathrm{Ca}^{2+}$-transport ATPase 3 gene (SERCA3) in Caucasian type II diabetic patients (UK Prospective Diabetes Study 48). Diabetologia 42: 1240-1243.

Vasanji Z, Cantor EJ, Juric D, Moyen M, Netticadan T. 2006. Alterations in cardiac contractile performance and sarcoplasmic reticulum function in sucrose-fed rats is associated with insulin resistance. Am J Physiol 291: C772-C780.

Vasanji Z, Dhalla NS, Netticadan T. 2004. Increased inhibition of SERCA2 by phospholamban in the type I diabetic heart. Mol Cell Biochem 261: 245-249.

Vericel E, Januel C, Carreras M, Moulin P, Lagarde M. 2004. Diabetic patients without vascular complications display enhanced basal platelet activation and decreased antioxidant status. Diabetes 53: 1046-1051.

Verkhratsky A. 2005. Physiology and pathophysiology of the calcium store in the endoplasmic reticulum of neurons. Physiol Rev 85: 201-279.

Verkhratsky A, Fernyhough P. 2008. Mitochondrial malfunction and $\mathrm{Ca}^{2+}$ dyshomeostasis drive neuronal pathology in diabetes. Cell Calcium 44: 112-122.

Vermassen E, Parys JB, Mauger JP. 2004. Subcellular distribution of the inositol 1,4,5-trisphosphate receptors: functional relevance and molecular determinants. Biol Cell 96: 3-17.

Vetter R, Rehfeld U, Reissfelder C, Weiss W, Wagner KD, Gunther J, Hammes A, Tschope C, Dillmann W, Paul M. 2002. Transgenic overexpression of the sarcoplasmic reticulum $\mathrm{Ca}^{2+}$ ATPase improves reticular $\mathrm{Ca}^{2+}$ handling in normal and diabetic rat hearts. FASEB $J \mathbf{1 6}$ 1657-1659.

Viner RI, Ferrington DA, Williams TD, Bigelow DJ, Schoneich C. 1999. Protein modification during biological aging: selective tyrosine nitration of the SERCA2a isoform of the sarcoplasmic reticulum $\mathrm{Ca}^{2+}$-ATPase in skeletal muscle. Biochem J 340: 657-669.

Wang XZ, Ron D. 1996. Stress-induced phosphorylation and activation of the transcription factor $\mathrm{CHOP}$ (GADD153) by p38 MAP Kinase. Science 272: 13471349. 
Wang HG, Pathan N, Ethell IM, Krajewski S, Yamaguchi Y, Shibasaki F, McKeon F, Bobo T, Franke TF, Reed JC. 1999. $\mathrm{Ca}^{2+}$-induced apoptosis through calcineurin dephosphorylation of BAD. Science 284: 339-343.

Wang M, Zhang WB, Zhu JH, Fu GS, Zhou BQ. 2010. Breviscapine ameliorates cardiac dysfunction and regulates the myocardial $\mathrm{Ca}^{2+}$-cycling proteins in streptozotocininduced diabetic rats. Acta Diabetol doi:101007/ s00592-009-0164-x.

Wehrens XH, Lehnart SE, Huang F, Vest JA, Reiken SR, Mohler PJ, Sun J, Guatimosim S, Song LS, Rosemblit $\mathrm{N}$, et al. 2003. FKBP12.6 deficiency and defective calcium release channel (ryanodine receptor) function linked to exercise-induced sudden cardiac death. Cell 113 829-840.

Wehrens XH, Lehnart SE, Marks AR. 2005a. Intracellular calcium release and cardiac disease. Annu Rev Physiol 67: 69-98.

Wehrens XH, Lehnart SE, Reiken S, van der Nagel R, Morales R, Sun J, Cheng Z, Deng SX, de Windt LJ, Landry DW, et al. 2005b. Enhancing calstabin binding to ryanodine receptors improves cardiac and skeletal muscle function in heart failure. Proc Natl Acad Sci 102: 9607-9612.

Wehrens XH, Lehnart SE, Reiken S, Vest JA, Wronska A, Marks AR. 2006. Ryanodine receptor/calcium release channel PKA phosphorylation: a critical mediator of heart failure progression. Proc Natl Acad Sci 103: 511-518.

Wei H, Perry DC. 1996. Dantrolene is cytoprotective in two models of neuronal cell death. J Neurochem 67: 2390-2398.

Wei H, Kim SJ, Zhang Z, Tsai PC, Wisniewski KE, Mukherjee AB. 2008a. ER and oxidative stresses are common mediators of apoptosis in both neurodegenerative and non-neurodegenerative lysosomal storage disorders and are alleviated by chemical chaperones. Hum Mol Genet 17: 469-477.

Wei H, Liang G, Yang H, Wang Q, Hawkins B, Madesh M, Wang S, Eckenhoff RG. 2008b. The common inhalational anesthetic isoflurane induces apoptosis via activation of inositol 1,4,5-trisphosphate receptors. Anesthesiology 108: $251-260$.

Wei Y, Wang D, Gentile CL, Pagliassotti MJ. 2009. Reduced endoplasmic reticulum luminal calcium links saturated fatty acid-mediated endoplasmic reticulum stress and cell death in liver cells. Mol Cell Biochem 331: 31-40.

White C, Li C, Yang J, Petrenko NB, Madesh M, Thompson CB, Foskett JK. 2005. The endoplasmic reticulum gateway to apoptosis by Bcl- $\mathrm{X}_{\mathrm{L}}$ modulation of the $\mathrm{InsP}_{3} \mathrm{R}$. Nat Cell Biol 7: 1021-1028.

Williams BL, Lipkin WI. 2006. Endoplasmic reticulum stress and neurodegeneration in rats neonatally infected with borna disease virus. J Virol 80: 8613-8626.

Wold LE, Dutta K, Mason MM, Ren J, Cala SE, Schwanke ML, Davidoff AJ. 2005. Impaired SERCA function contributes to cardiomyocyte dysfunction in insulin resistant rats. J Mol Cell Cardiol 39: 297-307.

Wu X, Sun L, Zha W, Studer E, Gurley E, Chen L, Wang X, Hylemon PB, Pandak WM Jr, Sanyal AJ, et al. 2010. HIV protease inhibitors induce ER stress and disrupt barrier integrity in intestinal epithelial cells. Gastroenterology 138: $197-209$.
Xiong ZG, Chu XP, Simon RP. 2007. Acid sensing ion channels-novel therapeutic targets for ischemic brain injury. Front Biosci 12: 1376-1386.

Xu C, Bailly-Maitre B, Reed JC. 2005. Endoplasmic reticulum stress: cell life and death decisions. J Clin Invest 115: 2656-2664.

Xu L, Eu JP, Meissner G, Stamler JS. 1998. Activation of the cardiac calcium release channel (ryanodine receptor) by poly-S-nitrosylation. Science 279: 234-237.

Yamada T, Ishihara H, Tamura A, Takahashi R, Yamaguchi S, Takei D, Tokita A, Satake C, Tashiro F, Katagiri H, et al. 2006. WFS1-deficiency increases endoplasmic reticulum stress, impairs cell cycle progression and triggers the apoptotic pathway specifically in pancreatic $\beta$-cells. Hum Mol Genet 15: 1600-1609.

Yamamoto K, Ichijo H, Korsmeyer SJ. 1999. BCL-2 is phosphorylated and inactivated by an ASK1/Jun N-terminal protein kinase pathway normally activated at $G_{2} / M$. Mol Cell Biol 19: 8469-8478.

Yang H, Liang G, Hawkins BJ, Madesh M, Pierwola A, Wei H. 2008. Inhalational anesthetics induce cell damage by disruption of intracellular calcium homeostasis with different potencies. Anesthesiology 109: 243-250.

Yano M, Kobayashi S, Kohno M, Doi M, Tokuhisa T, Okuda S, Suetsugu M, Hisaoka T, Obayashi M, Ohkusa T, et al. 2003. FKBP12.6-mediated stabilization of calciumrelease channel (ryanodine receptor) as a novel therapeutic strategy against heart failure. Circulation 107: $477-484$.

Yano M, Yamamoto T, Kobayashi S, Ikeda Y, Matsuzaki M. 2008. Defective $\mathrm{Ca}^{2+}$ cycling as a key pathogenic mechanism of heart failure. Circ J 72: A22-A30.

Yaras N, Ugur M, Ozdemir S, Gurdal H, Purali N, Lacampagne A, Vassort G, Turan B. 2005. Effects of diabetes on ryanodine receptor Ca release channel (RyR2) and $\mathrm{Ca}^{2+}$ homeostasis in rat heart. Diabetes 54: 3082-3088.

Ying J, Sharov V, Xu S, Jiang B, Gerrity R, Schoneich C, Cohen RA. 2008. Cysteine-674 oxidation and degradation of sarcoplasmic reticulum $\mathrm{Ca}^{2+}$ ATPase in diabetic pig aorta. Free Radic Biol Med 45: 756-762.

Yoneda T, Imaizumi K, Oono K, Yui D, Gomi F, Katayama T, Tohyama M. 2001. Activation of caspase-12, an endoplastic reticulum (ER) resident caspase, through tumor necrosis factor receptor-associated factor 2-dependent mechanism in response to the ER stress. J Biol Chem 276: $13935-13940$.

Yoshida H, Matsui T, Hosokawa N, Kaufman RJ, Nagata K, Mori K. 2003. A time-dependent phase shift in the mammalian unfolded protein response. Dev Cell 4: 265-271.

Yoshida H, Matsui T, Yamamoto A, Okada T, Mori K. 2001. XBP1 mRNA is induced by ATF6 and spliced by IRE1 in response to ER stress to produce a highly active transcription factor. Cell 107: 881-891.

Yoshida I, Monji A, Tashiro K, Nakamura K, Inoue R, Kanba S. 2006. Depletion of intracellular $\mathrm{Ca}^{2+}$ store itself may be a major factor in thapsigargin-induced ER stress and apoptosis in PC12 cells. Neurochem Int 48: 696-702.

Zalk R, Lehnart SE, Marks AR. 2007. Modulation of the ryanodine receptor and intracellular calcium. Annu Rev Biochem 76: 367-385. 
D. Mekahli et al.

Zbidi H, Redondo PC, Lopez JJ, Bartegi A, Salido GM, Rosado JA. 2010. Homocysteine induces caspase activation by endoplasmic reticulum stress in platelets from type 2 diabetics and healthy donors. Thromb Haemost 103: $1022-1032$.

Zhang S, Ong CN, Shen HM. 2004. Critical roles of intracellular thiols and calcium in parthenolide-induced apoptosis in human colorectal cancer cells. Cancer Lett 208: $143-153$.

Zhang L, Cannell MB, Phillips AR, Cooper GJ, Ward ML. 2008. Altered calcium homeostasis does not explain the contractile deficit of diabetic cardiomyopathy. Diabetes 57: 2158-2166.

Zhang Y, Chen HS, Khanna VK, De Leon S, Phillips MS, Schappert K, Britt BA, Browell AK, MacLennan DH. 1993. A mutation in the human ryanodine receptor gene associated with central core disease. Nat Genet 5: $46-50$.

Zhang Z, Lee YC, Kim SJ, Choi MS, Tsai PC, Xu Y, Xiao YJ, Zhang P, Heffer A, Mukherjee AB. 2007.
Palmitoyl-protein thioesterase-1 deficiency mediates the activation of the unfolded protein response and neuronal apoptosis in INCL. Hum Mol Genet 15: 337-346.

Zhong Y, Ahmed S, Grupp IL, Matlib MA. 2001. Altered SR protein expression associated with contractile dysfunction in diabetic rat hearts. Am J Physiol 281: H1137-H1147.

Zhou Y, Frey TK, Yang JJ. 2009. Viral calciomics: interplays between $\mathrm{Ca}^{2+}$ and virus. Cell Calcium 46: 1-17.

Zhou BQ, Hu SJ, Wang GB. 2006. The analysis of ultrastructure and gene expression of sarco/endoplasmic reticulum calcium handling proteins in alloxan-induced diabetic rat myocardium. Acta Cardiol 61: 21-27.

Zhou H, Pandak WM Jr, Lyall V, Natarajan R, Hylemon PB. 2005. HIV protease inhibitors activate the unfolded protein response in macrophages: implication for atherosclerosis and cardiovascular disease. Mol Pharmacol 68: 690-700. 


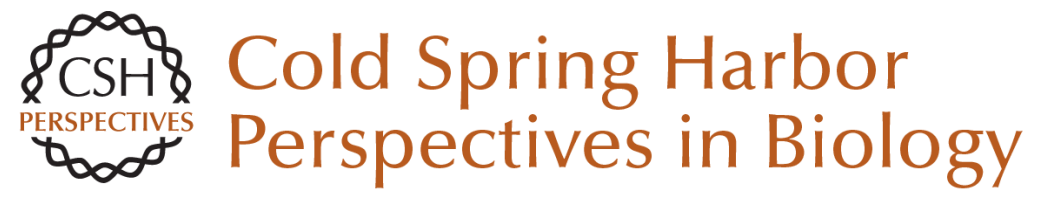

\section{Endoplasmic-Reticulum Calcium Depletion and Disease}

Djalila Mekahli, Geert Bultynck, Jan B. Parys, Humbert De Smedt and Ludwig Missiaen

Cold Spring Harb Perspect Biol 2011; doi: 10.1101/cshperspect.a004317 originally published online March 9, 2011

\section{Subject Collection Calcium Signaling}

The Endoplasmic Reticulum-Plasma Membrane Junction: A Hub for Agonist Regulation of $\mathrm{Ca}^{2+}$ Entry

Hwei Ling Ong and Indu Suresh Ambudkar

Calcium-Handling Defects and Neurodegenerative Disease

Sean Schrank, Nikki Barrington and Grace E. Stutzmann

Lysosomal $\mathrm{Ca}^{2+}$ Homeostasis and Signaling in Health and Disease

Emyr Lloyd-Evans and Helen Waller-Evans

\section{$\mathrm{Ca}^{2+}$ Signaling in Exocrine Cells}

Malini Ahuja, Woo Young Chung, Wei-Yin Lin, et al.

Functional Consequences of Calcium-Dependent Synapse-to-Nucleus Communication: Focus on Transcription-Dependent Metabolic Plasticity Anna M. Hagenston, Hilmar Bading and Carlos Bas-Orth

Identifying New Substrates and Functions for an Old Enzyme: Calcineurin Jagoree Roy and Martha S. Cyert

Fundamentals of Cellular Calcium Signaling: A Primer

Martin D. Bootman and Geert Bultynck
Primary Active $\mathrm{Ca}^{2+}$ Transport Systems in Health and Disease Jialin Chen, Aljona Sitsel, Veronick Benoy, et al.

Signaling through $\mathrm{Ca}^{2+}$ Microdomains from Store-Operated CRAC Channels Pradeep Barak and Anant B. Parekh

Structural Insights into the Regulation of $\mathrm{Ca}^{2+}$ /Calmodulin-Dependent Protein Kinase II (CaMKII) Moitrayee Bhattacharyya, Deepti Karandur and John Kuriyan

Store-Operated Calcium Channels: From Function to Structure and Back Again Richard S. Lewis

Bcl-2-Protein Family as Modulators of $\mathrm{IP}_{3}$

Receptors and Other Organellar $\mathrm{Ca} 2+$ Channels Hristina Ivanova, Tim Vervliet, Giovanni Monaco, et al.

Calcium Signaling in Cardiomyocyte Function Guillaume Gilbert, Kateryna Demydenko, Eef Dries, et al.

Cytosolic $\mathrm{Ca}^{2+}$ Buffers Are Inherently $\mathrm{Ca}^{2+}$ Signal Modulators Beat Schwaller

For additional articles in this collection, see http://cshperspectives.cshlp.org/cgi/collection/

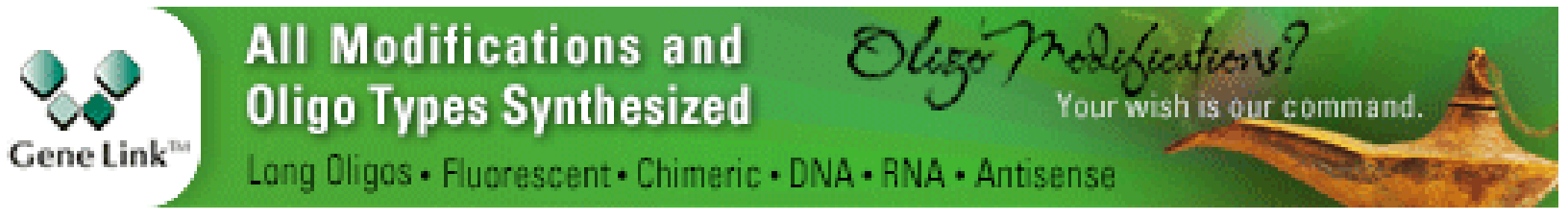


Role of Two-Pore Channels in Embryonic Development and Cellular Differentiation Sarah E. Webb, Jeffrey J. Kelu and Andrew L. Miller

\section{Organellar Calcium Handling in the Cellular \\ Reticular Network}

Wen-An Wang, Luis B. Agellon and Marek Michalak

For additional articles in this collection, see http://cshperspectives.cshlp.org/cgi/collection/

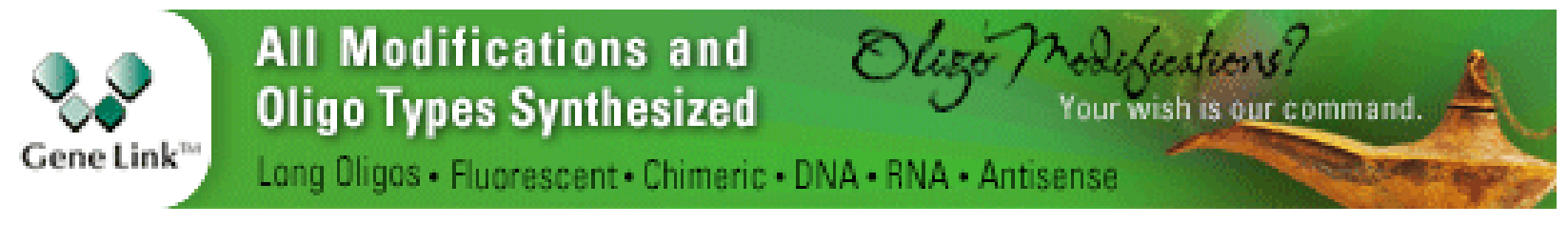

Copyright @ 2011 Cold Spring Harbor Laboratory Press; all rights reserved 